\title{
Geometry of shape of profiles of the sliding surface of ring seals in the aspect of friction losses and oil film parameters
}

\begin{abstract}
The article describes the results of simulations of the approved variations of sliding surfaces of ring seals in relation to a reference symmetrical barrel profile which is most often used in piston internal combustion engines. In particular the paper discusses the impact of the five assumed variants of sliding profiles of ring seals onto the thickness of oil film left on the cylinder face by a bottom and upper ring seal, the distribution of internal friction force in oil film between the ring seal set and the cylinder face, finally the oil film cover on a sliding surface of the upper ring seal.

The results presented in the article show a close relationship between the sliding surface profile of ring seals and a unit oil consumption. A relationship between these parameters for the elements lying in the movement plane of a wrist pin axis was proven, as well as for the one lying in the plane perpendicular to it. Exemplary parameters of oil film and friction losses were presented while assuming a constant total axial values of the height and depth of circumferential grooves. The shapes of these grooves on the sliding surface of the ring seals in free state can be made with electroerosion microprocessing or ablative laser microprocessing.
\end{abstract}

Key words: friction losses, profile of ring sliding surface, oil film, internal combustion engine

\section{Geometria profilu powierzchni ślizgowej pierścieni uszczelniających w aspekcie strat tarcia i parametrów filmu olejowego}

\begin{abstract}
W artykule omówiono wyniki badań symulacyjnych różnych wariantów profili powierzchni ślizgowej pierścieni uszczelniajacych w porównaniu do referencyjnego profilu baryłkowego symetrycznego. W szczególności przybliżono wptyw pięciu przykładowych wariantów profili powierzchni pierścieni uszczelniających na grubość warstwy oleju pozostawionej na gładzi cylindra przez dolny i górny pierścień uszczelniający, rozkład sity tarcia wewnętrznego w filmie olejowym między pakietem pierścieni uszczelniajacych a gładzia cylindra oraz przebieg pokrycia filmem olejowym profilu powierzchni górnego pierścienia uszczelniającego.

Zaprezentowane $w$ artykule wyniki badań wskazują na zależności jednostkowego zużycia oleju od profilu powierzchni ślizgowej pierścieni uszczelniających. Wykazano różnice tych zależności dla tworzacych leżących w płaszczyźnie ruchu osi sworznia tłokowego oraz w płaszczyźnie prostopadtej do tej płaszczyzny. Przedstawiono przykładowe parametry filmu olejowego i strat tarcia przy założeniu stałej sumarycznej wartości szerokości i glębokości rowków obwodowych. Rowki te systematyzowano $w$ wybranych kombinacjach na powierzchni ślizgowej pierścieni uszczelniajacych. Ksztatty tych rowków na powierzani ślizgowej pierścienia w stanie swobodnym otrzymuje się za pomoca mikroobróbki elektroerozyjnej i technologii ablacyjnej mikroobróbki laserowej.
\end{abstract}

Słowa kluczowe: straty tarcia, profil powierzchni ślizgowej pierścieni, film olejowy, silnik spalinowy

\section{Introduction}

Determining the share of friction losses in overall mechanical losses has been the subject of many theoretical and experimental papers $[1,2,7,8,9,11-15]$. The piston and ring seals and the scraper ring which are mounted there make up a mobile labyrinth seal with the cylinder liner. The basic function of the seal is to ensure the tightness of the combustion chamber. Nowadays most piston combustion engines contain two ring seals with cylinder barrel sliding surfaces, symmetrical and non-symmetrical.

The appropriateness of cooperation between a ring set and the cylinder piston and face are influenced by many factors, e.g.:

- friction heat flux absorbed by the piston-cylinder set,

- the flux of gases flowing through the combustion chambers of the cylinder to the crankcase,

\section{Wprowadzenie}

Określenie udziału strat tarcia tłokowych pierścieni uszczelniających w ogólnych stratach mechanicznych było przedmiotem wielu prac teoretycznych i doświadczalnych $[1,2,7,8,9]$. Tłok oraz osadzone na nim pierścienie uszczelniające i pierścień zgarniający tworzą $\mathrm{z}$ tuleją cylindrową ruchome uszczelnienie labiryntowe. Zasadniczym zadaniem tych pierścieni jest zapewnienie szczelności komory spalania. Obecnie w większości tłokowych silników spalinowych stosuje się dwa pierścienie uszczelniające o powierzchniach ślizgowych baryłkowych. Powierzchnie te mogą być symetryczne i niesymetryczne.

Na poprawność współpracy pierścieni uszczelniających i zgarniającego oraz gładzi cylindra wpływa wiele czynników:

- strumień ciepła tarcia absorbowany przez grupę tłokowo-cylindrową, 
- the lubricating oil flux infiltrated to the combustion chamber and irrevocably lost due to evaporation with exhaust gases,

- the intensity of wear of sliding surface of piston rings, piston ring grooves and cylinder face.

Each of the factors listed depends on geometrical proportions, i.e. piston lateral area, the scraper ring shelves, the lower and upper ring seal and the distribution of piston rings on the piston $[7,10,14]$. The friction resistance of ring seals depend among others on:

- the height and shape of the profile of ring sliding surface,

- the characteristics of materials applied,

- the distribution of piston compression ring pressure against the cylinder face, which are determined by ring elasticity and the operation of external forces,

- limiting errors of macroshapes of cylinder aperture (its roundness, straightness or concentricity),

- profiles of piston grooves,

- thermal strain of the piston and cylinder,

- oil dynamic viscosity

- the temperature of the components of the piston-cylinder set.

Based on the classic Newton model of fluid it can be assumed that friction losses e.g. in oil film between sliding surfaces of ring seal set and the cylinder face can be between several [W] and over 100 [W].

The most significant reduction of friction losses in the piston-cylinder assembly can be obtained by:

- limiting the number of ring seals,

- reducing the dynamic viscosity of oil,

- optimising the backlash between the piston rings and cylinder face, i.e. changing the distribution of unit pressure of sliding surface of piston rings against cylinder face,

- optimising the axial height of piston rings, in particular ring seals,

- changing the shape of sliding surface profile of piston rings,

- using the manipulation of the value of isochoric factor of pressure increase and engine rotational speed with consideration of piston-rings-cylinder assembly duration,

- using the coats characterised by low roughness and high resistance to wear during mixed friction.

Currently many methods of reducing friction losses are known in the cooperation between sliding surfaces of ring seals and the cylinder face. However, the technologies of precise processing of various materials used to produce piston rings and the opportunities to shape the profiles of sliding surfaces very accurately require more detailed simulation studies, as well as experimental studies of possibilities to reduce friction losses of ring seals.

\section{The boundary conditions assumed for simulation research}

Thanks to simulation models $[6,7]$ based on the hydrodynamic lubrication theory we can observe: the influence of sliding surface profile of seal rings onto friction losses,
- strumień gazów przepływających z komory spalania cylindra do skrzyni korbowej,

- strumień oleju smarującego infiltrowany do komory spalania i bezpowrotnie tracony wskutek odparowywania wraz z gazami spalinowymi,

- intensywność zużycia powierzchni ślizgowej pierścieni tłokowych, rowków pierścieniowych tłoka i gładzi cylindra.

Każdy z wymienionych czynników wynika z proporcji geometrycznych m.in. powierzchni bocznej tłoka, półek pierścienia zgarniającego, dolnego i górnego pierścienia uszczelniającego oraz rozmieszczenia pierścieni tłokowych na tłoku $[7,10,14]$. Z kolei opory tarcia pierścieni uszczelniających zależą od:

- wysokości i kształtu profilu powierzchni ślizgowej pierścieni,

- właściwości zastosowanych materiałów,

- rozkładu jednostkowych nacisków pierścieni na gładzi cylindra determinowanych sprężystością własną pierścieni i działaniem sił zewnętrznych,

- granicznych błędów makrokształtów otworu cylindrowego (jego okrągłości, prostoliniowości lub współosiowości),

- profili rowków tłokowych,

- odkształceń termicznych tłoka i cylindra,

- lepkości dynamicznej oleju,

- temperatury elementów grupy trokowo-cylindrowej.

Opierając się na klasycznym modelu newtonowskim cieczy, można przyjąć, że straty tarcia, np. w filmie olejowym między powierzchniami ślizgowymi pierścieni uszczelniających a gładzią cylindra, mogą zawierać się w granicach od kilkunastu $\mathrm{W}$ do wartości przekraczającej $100 \mathrm{~W}$.

Najbardziej znaczącą redukcję strat tarcia w grupie tłokowo-cylindrowej można osiągnąć przez:

- zmniejszenie liczby pierścieni uszczelniających,

- redukcję lepkości dynamicznej oleju,

- optymalizację luzu między pierścieniami tłoka a gładzią cylindra, tj. zmianę rozkładu jednostkowych nacisków powierzchni ślizgowych pierścieni tłokowych na gładź cylindra,

- optymalizację osiowej wysokości pierścieni tłokowych, w szczególności pierścieni uszczelniających,

- zmianę profilu powierzchni ślizgowej pierścieni tłokowych,

- wykorzystanie wariantowania wartości izochorycznego współczynnika przyrostu ciśnienia i prędkości obrotowej silnika z uwzględnieniem trwałości złożenia T-P-C,

- wykorzystanie powłok charakteryzujących się małą chropowatością i dużą odpornością na ścieranie w warunkach tarcia mieszanego.

Obecnie znanych jest wiele metod zmniejszania strat tarcia w zakresie współpracy powierzchni ślizgowych pierścieni uszczelniających z gładzią cylindra. Jednakże rozwijające się technologie precyzyjnej obróbki różnego rodzaju materiałów stosowanych do produkcji pierścieni tłokowych oraz możliwości dokładnego kształtowania ich profilu powierzchni ślizgowych wymagają dokładniejszych badań symulacyjnych i doświadczalnych w zakresie możliwości zmniejszenia strat tarcia pierścieni uszczelniających. 
a minimum thickness of oil film throughout the crankshaft rotation angle, the volume of oil squirted towards the combustion chamber of top dead centre in compression stroke and exhaust outlet, the covering of ring sliding surface with oil film and the pressure values in oil film.

A proper correlation of these parameters constitutes the basis for reducing friction losses. The author's concept of limiting friction losses in the piston-cylinder set by using the five selected shapes of ring seal profiles is justified, because if there is a gap between the sliding surface of ring seals and cylinder face, the gap does not have to be completely filled in with oil film. The concept assumes shaping the sliding surface of the ring covered with oil film in various values of the crankshaft rotation angle with various combinations of circumferential grooves.

Introducing the grooves on the sliding surface mostly leads to a slight increase in unit oil consumption. This can be prevented by shortening the distance between the lower and upper seal ring. The impact of shortening the distance of the lower seal ring and the scraping ring for the five selected profile variants on oil consumption is slight. Another limitation resulting from introducing the five selected variants of seal rings is decreasing the minimal oil film thickness in key piston positions, from $10^{\circ}$ to $20^{\circ}$ after top dead centre at the backing stroke, particularly for the work of the upper seal ring. This can be prevented by using in ring production the surfaces of low roughness, both on the cylinder surface and on the sliding surface of the piston rings up to $\mathrm{Rz}=0.150$ $\mu \mathrm{m}$. Then special coats of titanium aluminum nitrite TiAlCN, aluminum, titanium and chromium nitrites $\mathrm{AlCrTiN}$, aluminum and titanium nitrites ALTiN, and aluminium, titanium and silicon nitrites AlTiSiN must be used.

The simulation used the basic geometrical parameters of 170A.046 Fiat Cinquecento 700. The engine shall be used in experiments while implementing the concept of modification of sliding surfaces of seal rings, which will help to compare simulation and experiment results. The major parameters of the engine assumed in simulation are presented in Table 1 . The operational data, especially the engine rotational speed, oil dynamic viscosity and working temperature are necessary to choose the most suitable variants of seal ring profiles. If the minimal thickness of oil film 10o after top dead centre at the backing stroke and the requirements of covering the seal ring profiles with oil film are met, than their change, i.e. increasing the dynamic viscosity of oil or increasing the engine rotational speed will improve the conditions of cooperation between the surfaces of selected kinematic pairs.

In order to define the shape of a sliding profile of ring seals a modified model of a simulation program was used [1]. It defines a selected variant of a profile on the basis of 51 reference points on the axial height of a piston ring (Fig. 1). According to preliminary findings favourable parameters of the oil film can be used with very low values of circumferential groove depths - to $10 \mu \mathrm{m}$ - and the total width of the grooves of 300 $\mu \mathrm{m}$ for the lower ring seal and $400 \mu \mathrm{m}$ for the upper ring seal. These values constitute a $20 \%$ share in the axial height of

\section{Przyjęte warunki brzegowe do badań symulacyjnych}

Dzięki opracowanym modelom symulacyjnym $[6,7]$ opartym na hydrodynamicznej teorii smarowania obserwuje się: wpływ kształtu profilu powierzchni ślizgowych pierścieni uszczelniających na straty tarcia, minimalną grubość filmu olejowego w całym zakresie kąta obrotu wału korbowego, objętość oleju wyciskanego w kierunku komory spalania w GMP w suwie sprężania i wylotu spalin, pokrycie powierzchni ślizgowej pierścienia filmem olejowym i przebieg wartości ciśnień w filmie olejowym.

Określenie poprawnej korelacji pomiędzy tymi parametrami jest podstawą zmniejszenia strat tarcia. Autorska koncepcja zmniejszania strat tarcia $\mathrm{w}$ grupie tłokowo-cylindrowej przez zastosowanie wybranych pięciu wariantów kształtu profili pierścieni uszczelniających jest uzasadniona, ponieważ dla szczeliny między powierzchnią ślizgową pierścieni uszczelniających a gładzią cylindra nie ma potrzeby całkowitego wypełnienia tej szczeliny olejem, aby zapewnić ciągłość filmu olejowego. Koncepcja ta zakłada kształtowanie powierzchni ślizgowej pierścienia uszczelniającego, objętej filmem olejowym w różnych przedziałach kąta OWK, za pomocą utworzonych różnych kombinacji rowków obwodowych.

Podczas wprowadzania rowków na powierzchni ślizgowej obserwuje się w większości nieznaczne zwiększanie jednostkowego zużycia oleju. Można temu zapobiec, zmniejszając wzajemną odległość dolnego i górnego pierścienia uszczelniającego. Wpływ zmniejszenia odległości dolnego pierścienia uszczelniającego i pierścienia zgarniającego dla pięciu wybranych wariantów profili na zużycie oleju jest nieznaczny. Innym ograniczeniem wynikającym z wprowadzenia pięciu wybranych wariantów pierścieni uszczelniających jest zmniejszenie minimalnej grubości filmu olejowego, w newralgicznych położeniach troka, od $10^{\circ} \mathrm{do} 20^{\circ}$ po GMP w suwie rozprężania, szczególnie w zakresie pracy górnego pierścienia uszczelniającego. Można temu przeciwdziałać przez zastosowanie, na etapie produkcji pierścieni, powłok o małej chropowatości zarówno na powierzchni gładzi cylindra, jak i na powierzchni ślizgowej pierścieni tłokowych do wartości maksymalnej $\mathrm{Rz}=0,150 \mu \mathrm{m}$. Trzeba wtedy zastosować specjalne powłoki z węglikoazotku tytanu i glinu TiAlCN, powłoki z azotku glinu, chromu i tytanu AlCrTiN, powłoki z azotku glinu i tytanu AlTiN, powłoki z azotku glinu, tytanu i krzemu AlTiSiN.

Do badań symulacyjnych wykorzystano podstawowe parametry geometryczne silnika 170A.046 Fiata Cinquecento 700 . Silnik ten przy wdrażaniu koncepcji modyfikacji kształtu powierzchni ślizgowych pierścieni uszczelniających będzie wykorzystywany podczas badań doświadczalnych, co pozwoli porównać wyniki symulacji z wynikami doświadczalnymi. Ważniejsze parametry tego silnika przyjęte do badań symulacyjnych podano w tabeli 1. Przyjęte dane eksploatacyjne, zwłaszcza prędkość obrotowa silnika, lepkość dynamiczna oleju oraz temperatura pracy silnika, są potrzebne do doboru najbardziej odpowiednich wariantów profili pierścieni uszczelniających. Jeżeli minimalna grubo- 
Table 1. Selected engine parameters (170A.046) used in simulations of friction losses and oil film parameters

Tabela 1. Wybrane parametry silnika 170A.046 wykorzystane podczas badań symulacyjnych strat tarcia i parametrów filmu olejowego

\begin{tabular}{|c|c|c|c|}
\hline Parameter/parametr & Value/wartość & Parameter/parametr & Value/wartość \\
\hline $\begin{array}{l}\text { The angle of ring inclinere- } \\
\text { sulting from an incline of } \\
\text { piston axis towards piston } \\
\text { axis / kat pochylenia pierście- } \\
\text { nia wynikajacy z pochylenia } \\
\text { osi tloka względem osi } \\
\text { cylindra }\end{array}$ & $\alpha=0.0017 \mathrm{rad}$ & $\begin{array}{c}\text { Mean pressure of the upper ring seal/ } \\
\text { średni nacisk górnego pierścienia } \\
\text { uszczelniającego }\end{array}$ & $\mathrm{p}_{\mathrm{sr}-1}=0.2 \mathrm{MPa}$ \\
\hline $\begin{array}{l}\text { Oil dynamic viscosity/lepkość } \\
\text { dynamiczna oleju }\end{array}$ & $\eta=0.00152$ Pas & $\begin{array}{c}\text { Mean pressure of the lower ring seal/ } \\
\text { średni nacisk dolnegompierścienia } \\
\text { uszczelniającego }\end{array}$ & $\mathrm{p}_{\mathrm{st}-2}=0.2 \mathrm{MPa}$ \\
\hline Temperature & $\mathrm{T}=95^{\circ} \mathrm{C}$ & $\begin{array}{l}\text { Mean pressure of the scraper ring/ } \\
\text { średni nacisk pierścienia zgarnia- } \\
\text { jacego }\end{array}$ & $\mathrm{p}_{\mathrm{st}-3}=0.1 \mathrm{MPa}$ \\
\hline $\begin{array}{l}\text { Piston diameter/średnica } \\
\text { tłoka }\end{array}$ & $\mathrm{d}_{\mathrm{t}}=80 \mathrm{~mm}$ & $\begin{array}{l}\text { Distance between the upper and lo- } \\
\text { wer ring seals/odległość pierścienia } \\
\text { górnego i dolnego uszczelniajacego }\end{array}$ & $\mathrm{a}_{1}=4.7 \mathrm{~mm}$ \\
\hline Piston height/wysokość tloka & $\mathrm{h}_{\mathrm{t}}=40 \mathrm{~mm}$ & $\begin{array}{l}\text { Distance between the lower ring } \\
\text { seal and the scraper ring/odlegtość } \\
\text { pierścienia dolnego uszczelniajace- } \\
\text { go i zgarniajacego }\end{array}$ & $\mathrm{a}_{2}=7.5 \mathrm{~mm}$ \\
\hline $\begin{array}{l}\text { Axial height of the upper } \\
\text { ring of the ring seal/osiowa } \\
\text { wysokość górnego pierścienia } \\
\text { uszczelniajacego }\end{array}$ & $\mathrm{h}_{1}=1.50 \mathrm{~mm}$ & $\begin{array}{c}\text { Isochoric index of pressure increase/ } \\
\text { izochoryczny wspótczynnik przyrostu } \\
\text { ciśnienia }\end{array}$ & $\varphi_{c}=1.101$ \\
\hline $\begin{array}{l}\text { Axial height of the lower } \\
\text { ring of the ring seal/osiowa } \\
\text { wysokość dolnego pierścienia } \\
\text { uszczelniajacego }\end{array}$ & $\mathrm{h}_{2}=2.00 \mathrm{~mm}$ & $\begin{array}{l}\text { Compression politrope index/ } \\
\text { wyktadnik politropy sprężania }\end{array}$ & $\mathrm{n}_{1}=1.30$ \\
\hline $\begin{array}{l}\text { Axial height of the scraper } \\
\text { ring/osiowa wysokość } \\
\text { pierścienia zgarniającego }\end{array}$ & $\begin{array}{l}\mathrm{h}_{3}=4.00 \mathrm{~mm} \text { (ring } \\
\text { shelf height } / \text { wys. } \\
\text { pótki pierścienia } \\
\left.\mathrm{h}_{\mathrm{p}}=0.40 \mathrm{~mm}\right)\end{array}$ & $\begin{array}{l}\text { Backing politropeindex/wyktadnik } \\
\text { politropy rozprężania }\end{array}$ & $\mathrm{n}_{2}=1.35$ \\
\hline
\end{tabular}

ring seals with oil film in comparison with a reference value for piston rings in a particular engine. Simulations assumed a groove depth $=5 \mu \mathrm{m}$ for all the combinations of grooves on a profile of a sliding surface of ring seals. Adopting a constant value of circumferential groove depth and an additive width will enable to compare precisely the relations of change in friction resistance and their impact on oil film parameters.

Despite low values of circumferential groove depth and the required tolerance they can be executed with electric erosion mikroprocessing or ablative laser microprocessing. Assuming the grooves will be produced before the ring lock, they can be made with precise grinding with tolerance about $20 \mu \mathrm{m}$. However, such tolerance necessitates the application of deeper circumferential grooves, with other geometrical measurement of main mechanisms of the engine precisely defined. This is an additional reason to check in simulations the selected variants of circumferential grooves on the sliding surface of ring seals which could help limit friction losses of ring seals while maintaining good lubricating conditions. So far the execution of circumferential grooves about $5 \mu \mathrm{m}$ deep has not been technically possible due to the accuracy of the methods of processing, which is a gap not only in simulation, but also in experiments concerning the influence of profile shapes of sliding surface of ring seals on the reduction of friction ści filmu olejowego $10^{\circ}$ po GMP w suwie rozprężania oraz wymogi dotyczące pokrycia profilu pierścieni uszczelniających filmem olejowym będą spełnione dla wybranych wartości parametrów, to ich zmiana, czyli zwiększenie lepkości dynamicznej oleju albo zwiększenie prędkości obrotowej silnika poprawią warunki współpracy powierzchni wybranych par kinematycznych silnika.

Do określenia profilu powierzchni ślizgowej pierścieni uszczelniających wykorzystano zmodyfikowany model programu symulacyjnego [1], który określa wybrany wariant profilu na podstawie 51 punktów odniesienia na osiowej wysokości pierścienia tłokowego (rys. 1). Zgodnie $\mathrm{z}$ dotychczasową symulacją, korzystne parametry filmu olejowego można osiągnąć dzięki zastosowaniu bardzo małych wartości głębokości rowków obwodowych - do $10 \mu \mathrm{m}$ oraz sumarycznej szerokości rowków $300 \mu \mathrm{m}$ dla dolnego pierścienia uszczelniającego i $400 \mu \mathrm{m}$ dla górnego pierścienia. Wartości te stanowią 20procentowy udział w osiowej wysokości powierzchni ślizgowej pierścienia objętej filmem olejowym w stosunku do wartości referencyjnej pierścieni tłokowych danego silnika. W badaniach symulacyjnych przyjęto głębokość rowka równą $5 \mu \mathrm{m}$ dla wszystkich kombinacji rowków na profilu powierzchni ślizgowej pierścieni uszczelniających. Przyjęcie stałej wartości głębokości rowków obwodowych oraz jednakowej sumarycznej ich szerokości umożliwi dokładne porównanie zależności zmiany oporów tarcia i ich wpływu na parametry filmu olejowego od profilu powierzchni ślizgowej.

Pomimo nieznacznych wartości głębokości rowków obwodowych i wymaganej tolerancji wyrobu pierścieni $2 \mu \mathrm{m}$, ich wykonanie jest możliwe za pomocą mikroobróbki elektroerozyjnej lub technologii ablacyjnej mikroobróbki laserowej. Przy założeniu, że rowki obwodowe będą wytwarzane przed wykonaniem zamka pierścienia, dopuszcza się ich wykonanie metodą precyzyjnego szlifowania $z$ tolerancją około $20 \mu \mathrm{m}$. Taka tolerancja wymusza jednak stosowanie rowków obwodowych o większej głębokości, przy precyzyjnym ustaleniu pozostałych wymiarów geometrycznych mechanizmów głównych silnika. Stanowi to dodatkową motywację do weryfikacji w badaniach symulacyjnych wybranych wariantów rowków obwodowych na powierzchni ślizgowej, sprzyjających zmniejszeniu strat tarcia pierścieni uszczelniających przy zachowaniu dobrych warunków smarowania. Dotychczas wykonanie rowków obwodowych o głębokości $5 \mu \mathrm{m}$ nie było możliwe ze względu na małą dokładność obróbki, co stanowiło lukę nie tylko w badaniach symulacyjnych, ale również w eksperymentalnych. Główne 
a)

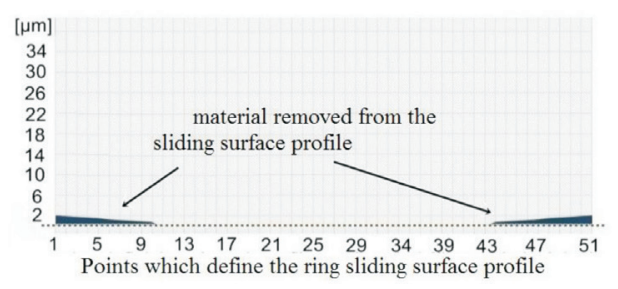

c)

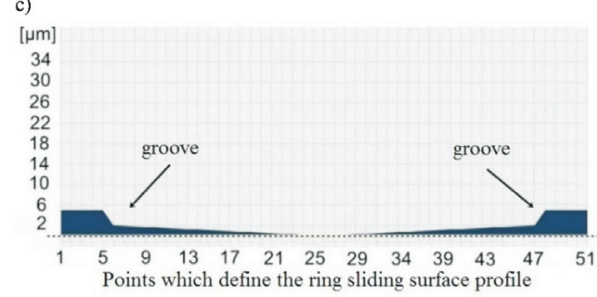

e)

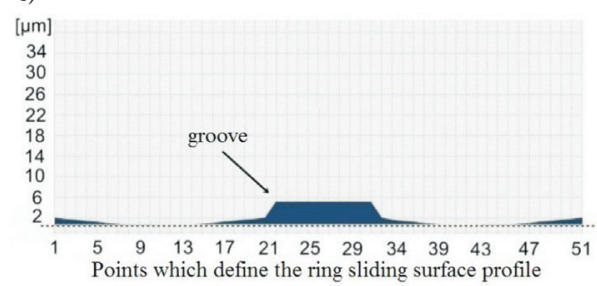

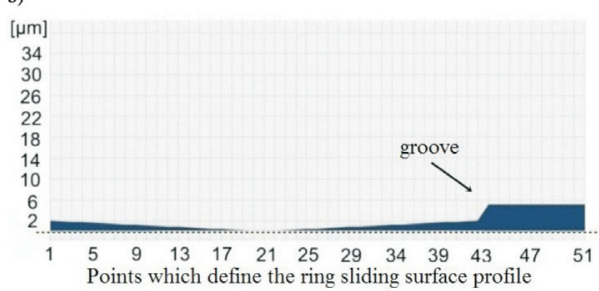

d)

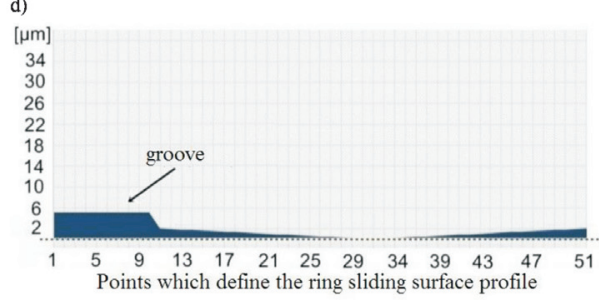

f))

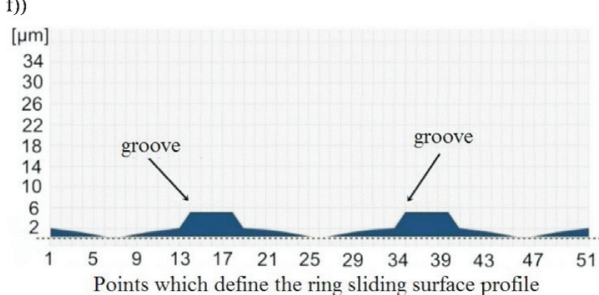

Fig.1. The profiles of sliding surface of ring seals: a) a reference profile b-f) variants $1-5$ of the ring seal sliding surface profile with circumferential grooves of $20 \%$ share in the axial width of reference ring and groove depth of $5 \mu \mathrm{m}$

Rys. 1. Profile powierzchni ślizgowej pierścieni uszczelniajacych: a) pierścień referencyjny, b-f) warianty 1-5 profili powierzchni ślizgowej z nałożonymi rowkami obwodowymi o 20-procentowym udziale w szerokości osiowej wysokości pierścienia referencyjnego i głębokości równej 5 um

losses in the piston-cylinder set. The repetitiveness of production of circumferential grooves on these surfaces with assumed tolerance of processing technology plays a key role in experiments. The characteristics of the processing and assuming optimal parameters with the durability requirements assumed is a major hindrance in analysing the phenomena between these surfaces.

For most ring seals oil film starts in convergence gap and finishes in the divergence gap. Undoubtedly the surface of separation of oil film is influenced by the oil surface tightness and the angle of oil drop adhesion to the surface it is on. It is difficult to identify the area precisely in simulation. The shaping of oil film is greatly influenced by the position of the profile of the ring sliding profile in relation to cylinder face defined by the value of the incline angle of piston rings resulting from the incline of piston axis to cylinder axis. The influence of the value of ring position angle on the values of oil film parameters for the five selected variants of sliding surface of profiles of ring seals must be taken into consideration while deciding on using the chosen variant of profile shape. To illustrate these relationships the angle value in simulations was assumed to be $\alpha=0.0017[\mathrm{rad}] \approx 0.097^{\circ}$. A disadvantageous choice of profile and its position in relation to cylinder face can lead to discontinuation of oil film, and thus will result in a dramatic increase of friction resistance in various segments of the crank rotation angle (depending on the profile variant). The assumed final variant of a sliding surface profile, particularly for the upper ring seal, allows to lower the oil film zadanie podczas badań doświadczalnych ma powtarzalność wyrobu rowków obwodowych na tych powierzchniach, przy założonej tolerancji technologii obróbki. Specyfika obróbki i przyjęcie optymalnych jej parametrów przy wymaganiach trwałości są dużym utrudnieniem $\mathrm{w}$ analizie zachodzących zjawisk pomiędzy powierzchniami ślizgowymi.

Dla większości pierścieni uszczelniających film olejowy zaczyna się w szczelinie konwergentnej i kończy w szczelinie dywergentnej. Niewątpliwie na obszar oddzielenia filmu olejowego wpływa napięcie powierzchniowe oleju oraz kąt przylegania kropli oleju do powierzchni, na której ona spoczywa. W badaniach symulacyjnych obszar ten jest trudny do jednoznacznej identyfikacji. Na kształtowanie się filmu olejowego znacznie wpływa ustawienie profilu powierzchni ślizgowej pierścienia względem gładzi cylindra, definiowane wartością kąta pochylania pierścieni tłokowych, wynikającego z pochylenia osi tłoka względem osi cylindra. Wpływ wartości kąta ustawienia pierścienia na parametry filmu olejowego dla pięciu wybranych wariantów profili powierzchni ślizgowych pierścieni uszczelniających musi być uwzględniony na etapie przyjmowania wariantu profilu. Dla uwidocznienia tych zależności do badań symulacyjnych przyjęto wartość kąta $\alpha=$ $=0,0017[\mathrm{rad}] \approx 0,097^{\circ}$. Niekorzystny dobór kształtu profilu i jego ustawienia względem gładzi cylindra może doprowadzić do zerwania filmu olejowego, a tym samym może spowodować gwałtowny przyrost oporów tarcia w różnych przedziałach kąta OWK. Przyjęcie ostatecznego wariantu profilu powierzchni ślizgowej górnego pierścienia uszczelniającego dopuszcza zmniejszenie grubości filmu olejowego do wartości, w której nie dochodzi do wystąpienia sprzyjających warunków do tarcia mieszanego. Ustalenie minimalnej wartości grubości filmu olejowego wymaga dokładniejszych badań doświadczalnych z zakresu tribologii, niemniej jednak za wartość dopuszczalną przyjmuje się obniżenie wartości lokalnej grubości filmu olejowego do $0,300 \mu \mathrm{m}$. Taka grubość filmu olejowego jest podyktowana przede wszystkim możliwymi technologiami uzyskiwania powierzchni ślizgowej pierścieni tłokowych i gładzi cylindra.

W wyniku niesymetrycznego położenia tłoka, siła tarcia ślizgowych powierzchni pierścieni tłokowych dla przyjętych wariantów profili może przyjmować różne wartości. 
thickness to the value at which there are not conditions for mixed friction. Determining a minimum thickness of oil film for these cases requires more detailed experiments in tribology, nevertheless, the admissible value is assumed the lowering of local thickness of oil film to $0.300 \mu \mathrm{m}$. Such thickness of oil film is mainly caused by possible technologies of production of piston ring and cylinder face sliding surfaces.

Due to non-symmetrical position of piston the friction of sliding surfaces of piston rings for the assumed profile variants can assume different values. The resulting torque generates a change in piston axis incline, thus changing the position of sliding surfaces of piston rings in relation to cylinder face. An analysis of the position of the five selected variants of ring seals for the elements located in the movement plane of the wrist pin and the characteristic elements of the cylinder to which the piston is pressed during the backing and compression strokes is necessary to define their share and influence onto total friction losses of the lower and upper ring seal, the local thickness of oil film between the mating surfaces, the covering of the selected profile variant of the ring sliding surface with oil film and the consumption of oil.

Figure 1 presents five conceptual variants of profiles of the ring seal sliding surface which are necessary to indicate the research directions to evaluate the possibilities to reduce friction losses and the values of all the vital oil film parameters which are possible technologically as well as a reference symmetrical barrel profile. The vertical axis in Fig. 1 describes the value of piston ring thickness in micrometers. The horizontal value shows the distribution points from 1 to 51 defining a shape of a given variant of ring seal sliding surface.

\section{Analysis of simulation results for selected variants of ring seals}

After the stroke resulting from the piston movement a ring leaves on the cylinder face a particular oil layer, which defines oil film parameters characteristic of the next piston rings. The values of oil layer thickness left on the cylinder face can be calculated based on a model of mathematical balance of fluxes [6].

An analysis of the function of lower ring seal depending on selected profile variants of the sliding surface led to significant conclusions. They result from stochastic parameters of oil film covering of a profile variant of a sliding surface of the lower piston ring and pressure values in oil film. Each preliminary considered variant of the profile of sliding surface of both ring seals should be considered individually in terms of the function of crankshaft rotation angle for the whole cycle of work and the changeable engine loads which occur there. In order to balance oil flows in the area of the lower ring seal it is necessary to correlate the local thickness of oil layer left on the cylinder face by the scraper ring with the location of the lower ring seal. A significant issue is the distance between the lower ring seal and the scraper ring as well as their total axial height covered with oil film. It is assumed based on theoretical considerations of the ef-
W efekcie powstaje moment obrotowy powodujący zmianę kąta nachylenia osi łłoka, a więc położenia powierzchni ślizgowej pierścieni tłokowych względem gładzi cylindra. Analiza położenia pięciu wybranych wariantów pierścieni uszczelniających dla tworzących leżących w płaszczyźnie ruchu osi sworznia tłokowego oraz dla charakterystycznych tworzących cylindra, do którego tłok jest dociskany w suwie rozprężania i w suwie sprężania, jest konieczna. Taka analiza umożliwia określenie wpływu położenia tłoka na całkowite straty tarcia dolnego i górnego pierścienia uszczelniającego, lokalną grubość filmu olejowego pomiędzy współpracującymi płaszczyznami, pokrycie wybranego wariantu profilu powierzchni ślizgowej pierścienia filmem olejowym oraz zużycie oleju.

Na rysunku 1 zaprezentowano pięć wariantów profili powierzchni ślizgowej pierścieni uszczelniających, niezbędnych do wyznaczenia kierunku badań możliwości redukcji strat tarcia i przebiegu najważniejszych parametrów filmu olejowego oraz referencyjny profil baryłkowy symetryczny. Na osi pionowej rys. 1 opisano wartość grubości rowków obwodowych umieszczonych na powierzchni ślizgowej pierścieni uszczelniających wyrażoną w mikrometrach. Oś pozioma przedstawia rozkład punktów od 1 do 51 definiujących kształt danego wariantu profilu powierzchni ślizgowej pierścienia uszczelniającego.

\section{Analiza wyników badań symulacyjnych wybranych wariantów pierścieni uszczelniających}

Pierścień po wykonaniu suwu wynikającego z ruchu tłoka pozostawia na gładzi cylindra warstwę oleju, która warunkuje parametry filmu olejowego charakterystyczne dla następnego z pierścieni tłokowych. Przebieg grubości warstwy oleju pozostawionej na gładzi cylindra można obliczyć na podstawie matematycznego modelu bilansu strumieni przepływów [6].

Analiza funkcji dolnego pierścienia uszczelniającego w aspekcie pięciu przyjętych wariantów profili powierzchni ślizgowej prowadzi do istotnych wniosków. Wynikają one ze stochastycznych parametrów pokrycia danego wariantu profilu powierzchni ślizgowej dolnego pierścienia tłokowego filmem olejowym oraz przebiegów ciśnień w filmie olejowym. Każdy z wstępnie wytypowanych wariantów profilu powierzchni ślizgowej obu pierścieni uszczelniających należy rozpatrywać osobno, w ujęciu funkcji kąta OWK dla całego cyklu pracy oraz występujących w nim zmiennych obciążeń silnika. Dla zbilansowania przepływów oleju w obszarze dolnego pierścienia uszczelniającego niezbędne jest skojarzenie lokalnej grubości warstwy oleju pozostawionej na gładzi cylindra przez pierścień zgarniający z położeniem dolnego pierścienia uszczelniającego. Istotna w tym aspekcie jest wzajemna odległość pierścieni dolnego uszczelniającego i zgarniającego oraz ich część profilu objęta filmem olejowym. Przyjęta na podstawie rozważań teoretycznych skuteczność referencyjnego pierścienia zgarniającego definiuje przedział kąta OWK, dla którego niektóre warianty profili powierzchni ślizgowych dolnego pierścienia uszczelniającego przejmują funkcję pierścienia 
ficiency of the reference scraper ring and defines the segment of crankshaft rotation angle for which the lower ring seal obtains the field of the scraper ring in terms of particular variants of sliding surface profiles. The role of the lower ring seal and a change in its function are closely related to the local thickness of oil layer left by the scraper ring on the cylinder face and a total distribution of unit pressures onto the cylinder face.

The even covering of sliding surface profile of the lower ring seal and the friction resistance are particularly important while defining the thickness of the oil film left on the cylinder face for the upper ring seal. The selection of a favourable profile of sliding surface of the lower seal ring which influences oil film parameters is less complicated than for the upper seal ring. This results from the impact of gas forces directly onto the surface of the upper seal ring.

Ensuring the conditions to obtain an even oil film between the selected variant of the sliding surface of the upper ring seal and the cylinder face is a main indicator of suiting the profile of both ring seals to the assumed operating conditions of the engine. A correlation of parameters, i.e. the covering of the sliding surface profile of the upper ring seal, a minimum thickness of oil film for selected ranges of the crankshaft rotation angle is necessary to reduce friction loss effectively for both rings. It is also necessary to maintain admissible values of the volume of oil scraped to the combustion chamber during the compression stroke and exhaust outflow as well as the durability of kinematic system.

The reduction of power absorbed by the lower ring seal is the same for the elements lying in the motion plane of the wrist pin and for all the assumed profiles of sliding surfaces in relation to the reference piston ring profile and equals $2 \mathrm{~W}$. A profile with central circumferential groove, i.e. variant 2 (Fig. 1c) of the profile of sliding surface of the lower ring seal is advantageous for the cylinder's characteristic element, to which the piston is pressed in compression stroke. Variant 5 (Fig. 1f), i.e. the profile with two internal and parallel circumferential groves, is disadvantageous, as it results in friction power increase by $26 \mathrm{~W}$. The other variants, namely 1,3 and 4 of sliding surface profiles of the lower ring seal result in reducing friction power by only $1 \mathrm{~W}$. With the cylinder element to which the pin is pressed in the compression and backing stroke variant 5 of the said profile generates friction power of $3 \mathrm{~W}$. In such case variant 2 of the profile also proves advantageous, as the friction power it generates for the element to which the pin is pressed in compression stroke is lower than a reference profile by $2 \mathrm{~W}$ and it is the same for the element to which the pin is pressed in the backing stroke. Variants 1 and 4 add $2 \mathrm{~W}$ to the increase in friction power for the element to which the pin is pressed during backing stroke. When analysing only this criterion, it can be claimed that variants 2 and 3 of the profile constitute a basis for optimal reduction of friction losses of the lower ring seal. Such a selection of profile variants for the sliding surface of the lower ring seal is incomplete, which is proved after a detailed analysis of friction loss and the evenness of film oil cover on the profile of the upper ring seal. After analysing zgarniającego. Rola dolnego pierścienia uszczelniającego oraz zmiana jego funkcji wykonawczej są ściśle związane z lokalną grubością warstwy oleju pozostawionej przez pierścień zgarniający na gładzi cylindra oraz rozkładem nacisków jednostkowych pierścienia na gładź cylindra.

Przebieg pokrycia profilu powierzchni ślizgowej dolnego pierścienia uszczelniającego oraz występujące opory tarcia są szczególnie ważne podczas definiowania grubości filmu olejowego, która pozostaje na gładzi cylindra dla górnego pierścienia uszczelniającego. Dobór korzystnego profilu powierzchni ślizgowej dolnego pierścienia uszczelniającego wpływającego na parametry filmu olejowego jest mniej skomplikowany niż dla górnego pierścienia uszczelniającego. Wynika to $\mathrm{z}$ oddziaływania sił gazowych bezpośrednio na powierzchnię roboczą górnego pierścienia uszczelniającego.

Zapewnienie warunków do powstania ciągłego filmu olejowego między wybranym wariantem powierzchni ślizgowej górnego pierścienia uszczelniającego a gładzią cylindra jest podstawowym wyznacznikiem dopasowania odpowiedniego profilu dla obu pierścieni uszczelniających do każdych warunków eksploatacji silnika. Korelacja parametrów pokrycia profilu powierzchni ślizgowej górnego pierścienia uszczelniającego z minimalną grubością filmu olejowego dla wybranych zakresów kąta OWK jest niezbędna do efektywnego zmniejszenia oporów tarcia obu pierścieni uszczelniających, przy czym konieczne jest zachowanie dopuszczalnych wartości objętości zgarnianego oleju do komory spalania w suwie sprężenia i wylotu spalin oraz trwałości złożenia kinematycznego.

Dla tworzących leżących w płaszczyźnie ruchu osi sworznia tłokowego redukcja mocy pochłanianej przez dolny pierścień uszczelniający dla wszystkich przyjętych wariantów profili powierzchni ślizgowych w stosunku do referencyjnego profilu pierścienia tłokowego jest taka sama i wynosi 2 W. Dla charakterystycznej tworzącej cylindra, do której tok jest dociskany w suwie sprężania korzystnie wypada wariant 2 (rys.1c), czyli profil z centralnie usytuowanym rowkiem obwodowym. Niekorzystny jest wariant 5 (rys. 1f), czyli profil z dwoma wewnętrznie równolegle położonymi rowkami obwodowymi, który prowadzi do przyrostu mocy tarcia o $26 \mathrm{~W}$. Pozostałe warianty 1, 3 i 4 (rys. 1b,d,e) profili powierzchni ślizgowej dolnego pierścienia uszczelniającego dają zmniejszenie mocy tarcia zaledwie o $1 \mathrm{~W}$. Dla tworzącej cylindra, do której tłok jest dociskany w suwie sprężania i rozprężania, wariant 5. profilu powierzchni ślizgowej dolnego pierścienia uszczelniającego generuje moc tarcia równą $3 \mathrm{~W}$. W tym przypadku wariant 2. profilu powierzchni ślizgowej wypada także korzystnie: generuje on bowiem moc tarcia dla tworzącej, do której tłok jest dociskany w suwie sprężania, mniejszą niż profil referencyjny o $2 \mathrm{~W}$ i równą dla tworzącej, do której tłok jest dociskany w suwie rozprężania. Warianty 1 i 4 powodują wzrost mocy tarcia dla tworzącej, do której trok jest dociskany w suwie rozprężania o $2 \mathrm{~W}$. Analizując te warianty, można stwierdzić, że warianty 2 i 3 profilu stanowią podstawę optymalnej redukcji strat tarcia dolnego pierścienia uszczelniającego. Taki dobór wariantów profili powierzchni ślizgowej dolnego pierścienia uszczelniającego 
the situation of circumferential grooves on sliding surfaces of the lower ring seal it can be concluded that variants 1,3 and 4 provide the best parameters of oil film coverage.

Figure 2 shows parameters of oil film and friction losses for a reference profile of the sliding surface of the upper ring seal in various piston positions.

Regardless of the profile variant the sliding surface of the upper ring seal in the motion between top dead centre and bottom dead centre encounters turning points of the lower rings, e.g the lower ring seal, which results in irregularities in the oil film thickness, especially in its thinning in the crucial turning point of the pint near the top dead centre in the backing stroke. Without long-term tribologic studies it is difficult to define how much the thickness of oil film can be lowered between the sliding surface of the upper ring seal and the cylinder face in the range of $5^{\circ}$ to $20^{\circ}$ crankshaft rotation angle after top dead centre in the backing stroke. The adopted area of the crankshaft rotation angle is considered the most crucial, as the pressure of the sliding surface profile of the upper ring seal with gas forces is the highest shortly after top dead centre to the cylinder face. After the ring passes from top dead centre to bottom dead centre a particular oil layer is left on the cylinder face. It partly evaporates because of the flame from the burnt fuel and air mixture. The amount of irretrievably lost oil film thickness in this case does not have a great influence on the reduction of oil film thickness in this range of crankshaft rotation angle for the upper ring seal.

In order to evaluate the effects of implementing selected variants of sliding surface profile of ring seals on the durability and reliability of engine the oil film thickness should be compared at $5^{\circ}$ and $10^{\circ}$ of crankshaft rotation angle after top dead centre in the backing stroke. These values for the cylinder characteristic elements lying in the motion plane of the piston axis and in extreme positions, in which the piston is pressed in the backing and compression strokes are presented in Table 2. It can be assumed that the increase of the convex of the sliding surface profile of ring seals, i.e. the lowering of the circumferential groove determines a reduction of the values of extrusion effect index and the index considerably determines the oil film thickness. This is why profiles of variants 1,3 and 4 are the best in such jest niekompletny, co stwierdza się po szczegółowej analizie mocy tarcia i przebiegu pokrycia filmem olejowym profilu górnego pierścienia uszczelniającego. Analizując ułożenie rowków obwodowych na powierzchniach ślizgowych dolnego pierścienia uszczelniającego, stwierdza się, że najlepsze parametry pokrycia filmem olejowym tego profilu uzyskuje się dla wariantów 1, 3, 4 .

$\mathrm{Na}$ rysunku 2 przedstawiono parametry filmu olejowego i straty tarcia dla referencyjnego profilu powierzchni ślizgowej górnego pierścienia uszczelniającego w różnych położeniach tłoka.

Niezależnie od wariantu profilu powierzchni ślizgowej górnego pierścienia uszczelniającego, podczas ruchu między GMP i DMP napotyka on na punkty zwrotne niżej leżących pierścieni, m.in. dolnego pierścienia uszczelniającego, co prowadzi do nieregularności przebiegu grubości filmu olejowego, a zwłaszcza jego zmniejszenia w krytycznym punkcie zwrotnym tłoka w pobliżu GMP w suwie rozprężania. Bez długotrwałych badań tribologicznych trudno jest określić, do jakiej wartości można zmniejszyć grubość filmu olejowego między powierzchnią ślizgową górnego pierścienia uszczelniającego a gładzią cylindra, w zakresie od $5^{\circ}$ do $20^{\circ}$ OWK po GMP w suwie rozprężania. Przyjęty obszar kąta OWK uważa się za najbardziej newralgiczny, ponieważ docisk profilu powierzchni ślizgowej górnego pierścienia uszczelniającego do gładzi cylindra siłami gazowymi tuż po GMP jest największy. Po przejściu pierścienia z GMP do DMP na gładzi cylindra pozostaje warstwa oleju, która ulega częściowemu odparowaniu w wyniku oddziaływania płomienia spalanej mieszanki paliwowo-powietrznej na gładź cylindra. Ilość traconej bezpowrotnie grubości filmu olejowego dla tego przypadku nie ma dużego wpływu na zmniejszenie grubości filmu olejowego w tym zakresie kąta OWK dla górnego pierścienia uszczelniającego.

Chcąc ocenić wpływ wybranych 5. wariantów profili powierzchni ślizgowych pierścieni uszczelniających na trwałość i niezawodność pracy silnika, należy porównać grubość filmu olejowego $5^{\circ}$ i $10^{\circ} \mathrm{OWK}$ po GMP w suwie rozprężania. Przebieg tych wartości dla charakterystycznych tworzących cylindra, leżących w płaszczyźnie ruchu osi sworznia tłokowego oraz w skrajnych położeniach,
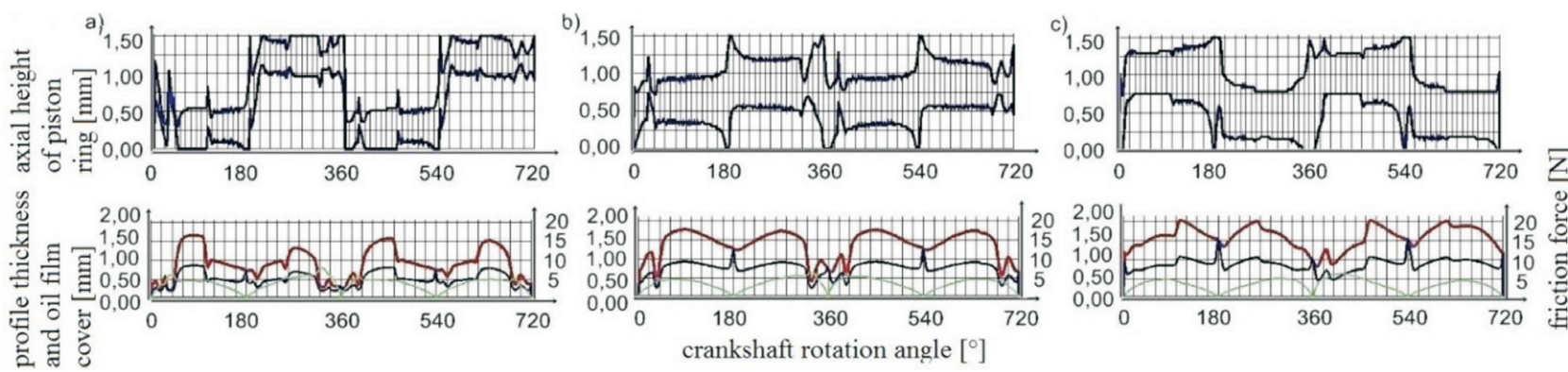

Fig. 2. Change of oil film area of a barrel profile of an upper ring seal (reference) - blue line, the evenness of oil film thickness - red line, friction forces - green line in the function of crank position angle: a) for the element in the motion plane to which the piston is pressed in backing stroke $\mathrm{L}$ (Table 2), b) for the characteristics elements of $\mathrm{M}$ - wrist pin axis, c) $\mathrm{R}$ - in the compression stroke

Rys. 2. Zmiana obszaru pokrycia baryłkowatego profilu górnego pierścienia uszczelniającego (referencyjnego) filmem olejowym - linia niebieska, przebieg grubości filmu olejowego - linia czerwona, sity tarcia - linia zielona w funkcji OWK : a) dla charakterystycznej tworzacej cylindra, do której ttok jest dociskany w suwie rozprężania L (tab. 2), b) dla tworzących leżacych w płaszczyźnie ruchu osi sworznia tlokowego M, c) w suwie sprężania $R$ 
Table 2. Distribution of oil film thickness $5^{\circ}$ and $10^{\circ}$ after top dead centre and friction forces $20^{\circ}$ after top dead centre in the backing stroke for selected profile variants of the sliding surface of the upper ring seal: a) for the elements lying in the motion plane of piston axis: $\mathrm{M}, \mathrm{b}$ ) for the characteristic element of the cylinder to which the piston is pressed in the backing stroke: $\mathrm{L}, \mathrm{c})$ in the compression stroke: $\mathrm{R}$

Tabela 2. Rozkład grubości filmu olejowego $5^{\circ} i 10^{\circ}$ po GMP oraz sity tarcia $20^{\circ}$ po GMP w suwie pracy dla wybranych wariantów profili powierzchni ślizgowych górnego pierścienia uszczelniającego

\begin{tabular}{|c|c|c|c|c|}
\hline $\begin{array}{l}\text { Variant of a } \\
\text { sliding profile of } \\
\text { a ring/wariant } \\
\text { profilu powi- } \\
\text { erzchni ślizgowej } \\
\text { pierścienia }\end{array}$ & $\begin{array}{l}\text { Position of the } \\
\text { piston versus } \\
\text { cylinder face/ } \\
\text { potożenie ttoka } \\
\text { względem gtadzi } \\
\text { cylindra }\end{array}$ & $\begin{array}{c}\text { Oil film } \\
\text { thickness } 5^{\circ} \\
\text { after dead point } \\
\text { centre/grubość } \\
\text { filmu olejowego } \\
5^{\circ} \text { po } G M P[\mu \mathrm{m}]\end{array}$ & $\begin{array}{l}\text { Oil film thickness } \\
10^{\circ} \text { after point } \\
\text { dead centre/ } \\
\text { grubość filmu } \\
\text { olejowego } 10^{\circ} \\
\text { po GMP }[\mu \mathrm{m}]\end{array}$ & $\begin{array}{c}\text { Friction force } 20^{\circ} \\
\text { after dead point } \\
\text { centre in backing } \\
\text { stroke/sita tarcia } \\
\text { po GMP w suwie } \\
\text { rozprężania }[\mathrm{N}]\end{array}$ \\
\hline \multirow[t]{3}{*}{1} & M & 0.230 & 0.430 & 3.6 \\
\hline & $\bar{L}$ & 0.241 & 0.385 & 3.4 \\
\hline & $\mathrm{R}$ & 0.208 & 0.344 & 4.1 \\
\hline \multirow[t]{3}{*}{2} & $M$ & 0.450 & 0.439 & 8.6 \\
\hline & $\mathrm{L}$ & 0.203 & 0.256 & 2.6 \\
\hline & $\mathrm{R}$ & 0.518 & 0.444 & 4.5 \\
\hline \multirow[t]{3}{*}{3} & $\mathrm{M}$ & 0.223 & 0.400 & 8.6 \\
\hline & $\mathrm{L}$ & 0.231 & 0.372 & 3.6 \\
\hline & $\mathrm{R}$ & 0.205 & 0.314 & 4.6 \\
\hline \multirow[t]{3}{*}{4} & M & 0.247 & 0.464 & 3.3 \\
\hline & $\mathrm{L}$ & 0.253 & 0.406 & 31 \\
\hline & $\mathrm{R}$ & 0.263 & 0.386 & 3.6 \\
\hline \multirow[t]{3}{*}{5} & $\mathrm{M}$ & 0.202 & 0.200 & 17.3 \\
\hline & $\mathrm{L}$ & 0.200 & 0.256 & 12.2 \\
\hline & $\mathrm{R}$ & 0.506 & 0.391 & 4.2 \\
\hline \multirow{3}{*}{$\begin{array}{l}\text { Reference/ } \\
\text { referencyjny }\end{array}$} & M & 0.657 & 0.711 & 4.3 \\
\hline & $\mathrm{L}$ & 0.269 & 0.359 & 4.0 \\
\hline & $\mathrm{R}$ & 0.836 & 0.852 & 4.9 \\
\hline
\end{tabular}

conditions of kinematic pairs cooperation. Reduction of oil film thickness of $10^{\circ}$ after top dead centre in the backing stroke for the cylinder element lying in the motion plane of the piston for profiles 1,3 and 4 is $39.53 \%, 38.26 \%$ and $34.74 \%$ respectively. For the other cylinder elements lying in extreme positions, particularly in the backing stroke, the oil film thickness for variants 1,3 and 4 is more favourable than for variants 2 and 5 . This refutes an earlier hypothesis according to which variants 2 and 5 of the profiles of sliding surfaces of ring seals with circumferential grooves placed in the middle of the area were more promising than variants 1 , w których tłok jest dociskany w suwie rozprężania i sprężania, przedstawiono w tabeli 2 . Można przyjąć, że wzrost wypukłości profilu powierzchni ślizgowej pierścieni uszczelniających, a więc zwiększanie głębokości rowka obwodowego wywołuje redukcję wartości wskaźnika efektu wyciskania, a wskaźnik ten w dużej mierze decyduje o grubości filmu olejowego. Z tego względu w tych warunkach współpracy powierzchni par kinematycznych korzystnie przedstawiają się profile wariantów 1, 3 i 4. Redukcja grubości filmu olejowego $10^{\circ}$ po GMP w suwie rozprężania dla tworzącej cylindra, leżącej w płaszczyźnie ruchu osi sworznia tłokowego, wynosi dla profili wariantów 1, 3 i 4 odpowiednio: 39,53\%, $38,26 \%$ i $34,74 \%$. Dla pozostałych tworzących cylindra, leżących w skrajnych położeniach, a w szczególności w suwie rozprężania, lokalna grubość filmu olejowego dla wariantów 1, 3 i 4 jest bardziej korzystna niż dla wariantów 2 i 5. Powoduje to odrzucenie wcześniejszej tezy, że warianty 2 i 5 profili powierzchni ślizgowych pierścieni z rowkami obwodowymi, umieszczonymi po środku tej powierzchni, są bardziej korzystne niż warianty 1, 3 i 4 profili z rowkami umieszczonymi na ich zewnętrznych krawędziach w różnych położeniach i różnych wymiarach geometrycznych.

$\mathrm{Na}$ rysunkach 2-6 zauważa się znaczne zmniejszenie siły tarcia $20^{\circ}$ OWK po GMP w suwie rozprężania dla wariantu 1. w stosun$\mathrm{ku}$ do profilu referencyjnego oraz profilu z wariantu 2. Zmniejszenie siły tarcia dla wariantu profili 1 i 4 jest bardzo duże i wynosi dla tworzącej cylindra i względnego położenia tłoka oznaczonego literą M odpowiednio: $16,28 \%$ i 23,26\%. Dla tworzących oznaczonych literami L i R obserwuje się również korzystną zmianę wartości siły tarcia $20^{\circ} \mathrm{OWK}$ po GMP w suwie rozprężania dla wariantów 1 i 4 . Dla większych prędkości obrotowych silnika oraz dla większej wartości współczynnika izochorycznego
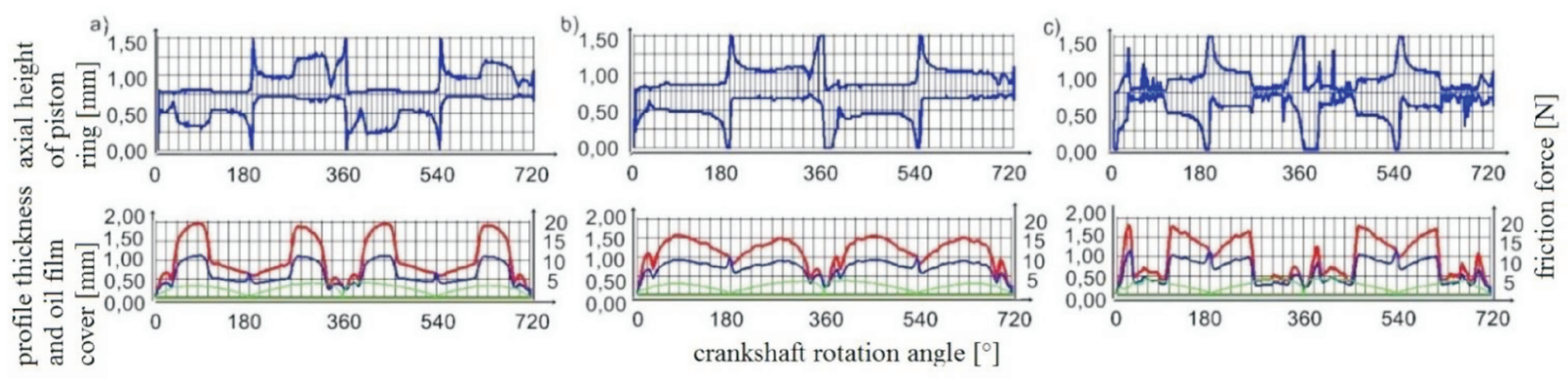

Fig. 3. Change in the area of oil film cover of version 1 of the profile of upper ring seal - blue line, the evenness of oil film - red line, friction forces - green line in the function of crank position angle: a) for the elements lying in the motion plane of the wrist pin $\mathrm{M}$, b) for the characteristic cylinder element to which the piston is pressed in the backing stroke $\mathrm{L}, \mathrm{c}$ ) in the compression stroke $\mathrm{R}$

Rys. 3. Zmiana obszaru pokrycia 1. wersji profilu górnego pierścienia uszczelniającego filmem olejowym - linia niebieska, przebieg grubości filmu olejowego - linia czerwona, siły tarcia - linia zielona w funkcji kąta położenia korby: a) dla charakterystycznej tworzącej cylindra, do której tłok jest dociskany $w$ suwie rozprężania $L$, b) dla tworzacych leżących w płaszczyźnie ruchu osi sworznia tłokowego $M$, c) w suwie sprężania $R$ 

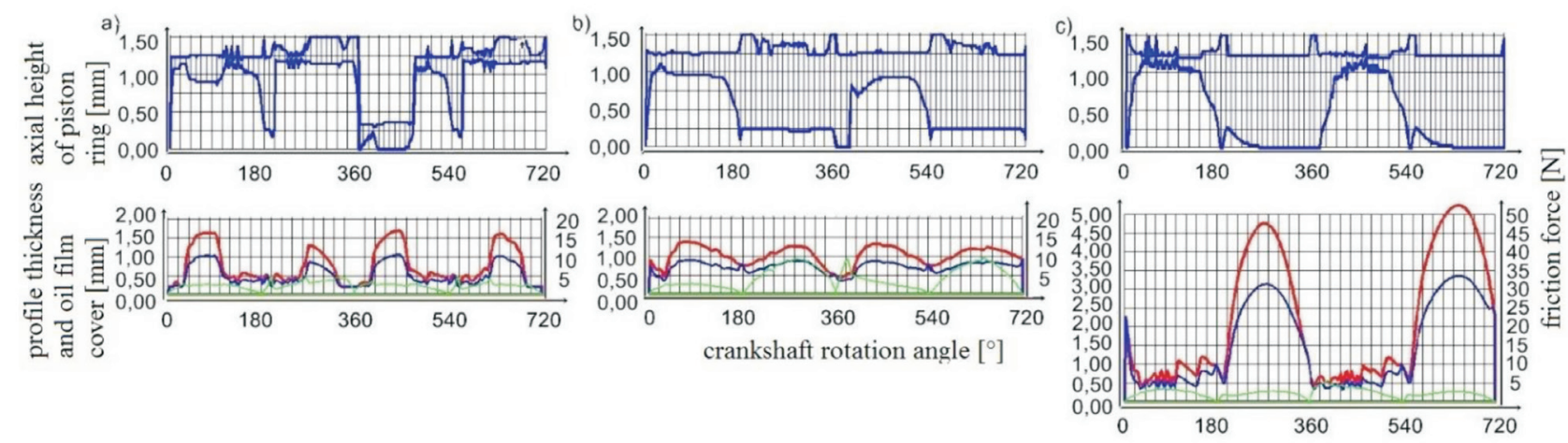

Fig. 4. Change in the evenness of oil film cover of version 2 of the upper ring seal - blue line, the evenness of oil film thickness - red line, friction force in function of crank position angle - green line: a) for the characteristic cylinder element to which the piston is pressed in the backing stroke - $\mathrm{L}$, b) for the characteristic cylinder element to which the piston is pressed in the backing stroke $-\mathrm{L}$, c) in the compression stroke $-\mathrm{R}$

Rys. 4. Zmiana obszaru pokrycia 2. wersji profilu górnego pierścienia uszczelniającego filmem olejowym - linia niebieska, przebieg grubości filmu olejowego - linia czerwona, sity tarcia - linia zielona w funkcji kąta położenia korby: a) dla charakterystycznej tworzacej cylindra, do której ttok jest dociskany w suwie rozprężania $L, b)$ dla tworzacych leżacych w płaszczyźnie ruchu osi sworznia tłokowego $M$, c) w suwie sprężania $R$

3 and 4 of the profiles with grooves placed on the outer edges in various positions and geometrical measurements.

Figures 2-6 indicate a significant reduction in the friction force $20^{\circ}$ crankshaft rotation angle after top dead centre in the backing stroke for variant 1 in comparison with the reference profile and the profile of variant 2 . Reducing the friction force for variants 1 and 4 is highly significant and stopnia przyrostu ciśnienia redukcja wartość sił tarcia $20^{\circ}$ po GMP w suwie rozprężania oraz całkowita moc tarcia pochłaniana przez pierścienie uszczelniające ulegają znacznemu zmniejszeniu w stosunku do profilu referencyjnego.

Warianty 2 i 5 profili powierzchni ślizgowej pierścieni uszczelniających ocenia się bardzo niekorzystnie pod względem strat tarcia powodowanych przez górny pierścień
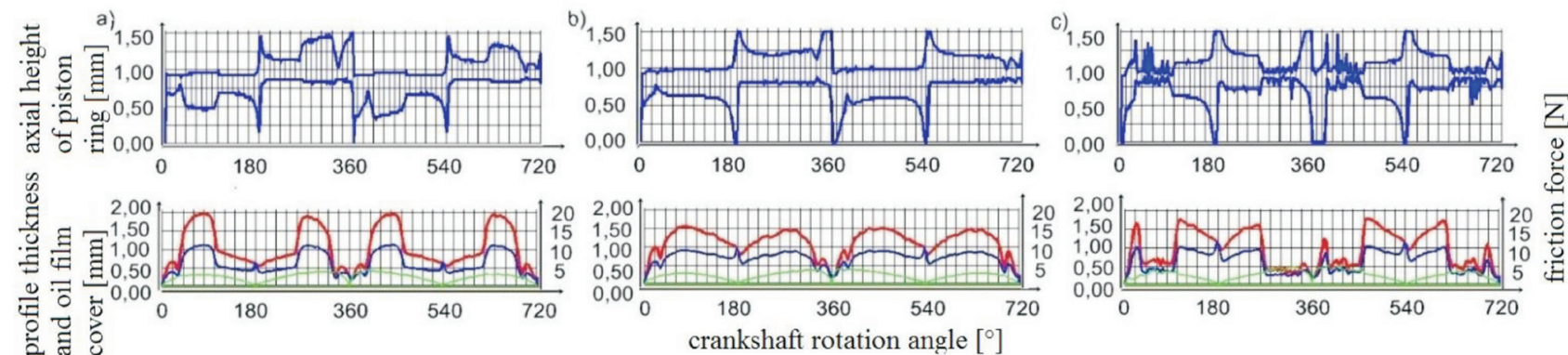

Fig. 5. Change in the evenness of oil film cover of version 3 of the upper ring seal - blue line, the evenness of oil film thickness - red line, friction force in function of crank position angle - green line: a) for the characteristic cylinder element to which the piston is pressed in the backing stroke L, b) for the characteristic cylinder element to which the piston is pressed in the backing stroke $\mathrm{L}, \mathrm{c}$ ) in the compression stroke $\mathrm{R}$

Rys. 5. Zmiana obszaru pokrycia 3. wersji profilu górnego pierścienia uszczelniajacego filmem olejowym - linia niebieska, przebieg grubości filmu olejowego - linia czerwona, sity tarcia - linia zielona w funkcji kąta położenia korby: a) dla charakterystycznej tworzącej cylindra, do której tłok jest dociskany $w$ suwie rozprężania $L, b)$ dla tworzacych leżacych w płaszczyźnie ruchu osi sworznia tłokowego $M, c)$ w suwie sprężania $R$
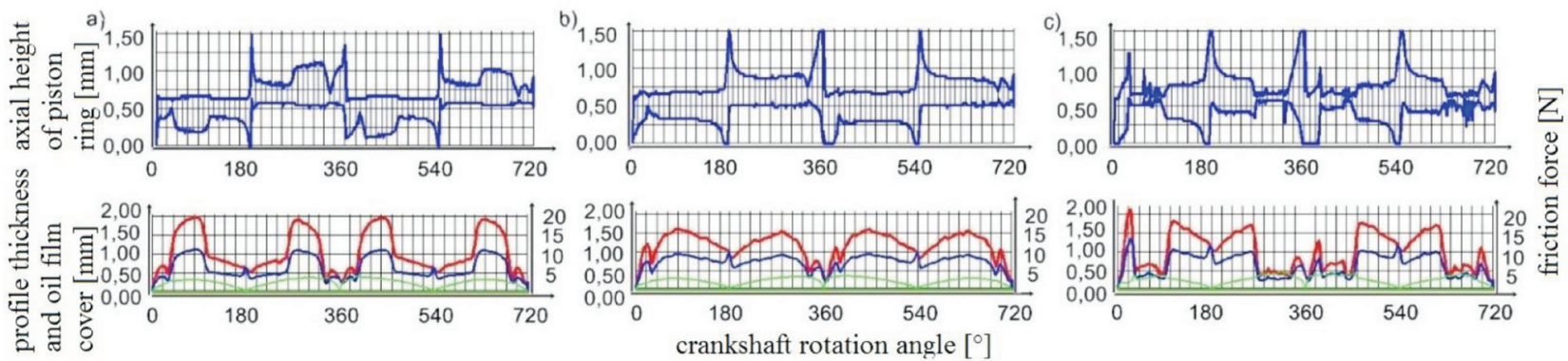

Fig. 6. Change in the evenness of oil film cover of version 4 of the upper ring seal - blue line, the evenness of oil film thickness - red line, friction force in function of crank position angle - green line: a) for the characteristic cylinder element to which the piston is pressed in the backing stroke L, b) for the characteristic cylinder element to which the piston is pressed in the backing stroke L, c) in the compression stroke $\mathrm{R}$

Rys. 6. Zmiana obszaru pokrycia 4. wersji profilu górnego pierścienia uszczelniającego filmem olejowym - linia niebieska, przebieg grubości filmu olejowego - linia czerwona, sity tarcia - linia zielona w funkcji kąta położenia korby: a) dla charakterystycznej tworzacej cylindra, do której tłok jest dociskany w suwie rozprężania $L$, b) dla tworzacych leżacych w płaszczyźnie ruchu osi sworznia tłokowego $M$, c) w suwie sprężania $R$ 
for the cylinder element and relative piston position marked with $\mathrm{M}$ is $16.28 \%$ and $23.26 \%$ respectively, for the elements marked with the letters $\mathrm{L}$ and $\mathrm{R}$ also an advantageous change in the friction force value $20^{\circ}$ crankshaft rotation angle after top dead centre is observed in the backing stroke for variants 1 and 4. For higher rotational speeds of the engine and a higher value of the isochoric index of pressure increase rate the reduction in friction $20^{\circ}$ after top dead centre during the backing stroke and the total friction power absorbed by the ring seals is considerably limited in comparison with the reference profile variant of the ring seal.

Variants 2 and 5 of the profiles of sliding surface of ring seals are very disadvantageous in terms of friction losses generated by the upper ring seal. After an analysis of Fig. 4 and Table 2 a significant increase in friction forces in all the scope of crankshaft rotation angle is found for the five variants of profiles of sliding surface of ring seals. Adapting the variants with two or more circumferential grooves placed in the middle of axial height of a sliding surface profile of ring seals helps greatly reduce oil film thickness between the upper ring seal and cylinder face and leads to increased friction losses by the upper ring seal. It must be reminded that the profiles are adopted simultaneously for the lower and upper seal ring.

An increased load influence on the friction force for the five selected profile variants occurs only in the backing stroke and for low values of the crankshaft rotation angle value. Such a characteristics means that an average value of friction pressure in oil film for a loaded and unloaded engine will be comparable for selected profile variants of the sliding surfaces of both ring seals. Even the value of the minimum oil film thickness at crucial points of piston position between the sliding surface of the upper ring seal and the cylinder face in the backing stroke, assuming any variant of the profiles, does not significantly change in terms of discontinuation of oil film coverage. This is caused by unloading effect of boundary pressure in the spot of oil film discontinuation.

An important parameter deciding on the choice of an optimal variant of a profile of a sliding surface of ring seals is its influence on the pressure of the upper ring seal to cylinder face with gas forces and consequently the volume of oil squirted towards the combustion chamber $\mathrm{V}_{2}$ and $\mathrm{V}_{4}$. After converting the volume values a single and hourly oil consumption can be obtained. The volume of oil scraped during compression and outflow is mainly influenced by the oil film layer on the sliding surface. Based on simulation results it can be assumed that oil consumption significantly increases after a change of shapes in variants $1-5$ of sliding surface profiles of ring seals in comparison with the reference profile of the ring seal. This fact greatly complicates the reason for applying the above variants of sliding surface profiles of ring seals in order to control friction losses of ring seals. Despite these limitations it can be seen that variants 1,3 and 4 have the best characteristics in comparison with the other variants of ring seal profiles. This is due to advantageous covering of the sliding surface profile of ring seals with oil film. Also in real conditions implementing grooves from variants 1, 3 and 4 will lead to increased unit pressure uszczelniający oraz pokrycia ich profilu filmem olejowym. $\mathrm{Na}$ podstawie analizy rysunku 4 i tabeli 2 stwierdza się znaczny wzrost sił tarcia w całym zakresie kąta OWK dla przyjętych pięciu wariantów profili powierzchni ślizgowych pierścieni uszczelniających. Wprowadzenie profili o dwóch lub więcej rowkach obwodowych umieszczonych po środku osiowej wysokości profilu powierzchni ślizgowej, sprzyja znacznej redukcji grubości filmu olejowego pomiędzy górnym pierścieniem uszczelniającym a gładzią cylindra oraz prowadzi do zwiększenia strat tarcia przez górny pierścień uszczelniający. Należy tu przypomnieć, że dane profile są przyjęte równocześnie dla dolnego i górnego pierścienia uszczelniającego.

Wpływ wzrostu obciążenia na wartość siły tarcia dla pięciu wybranych wariantów profili występuje wyłącznie w suwie rozprężania silnika dla niewielkich wartości kąta OWK. Taka właściwość oznacza, że średnia wartość ciśnienia tarcia w filmie olejowym dla silników obciążanego i nieobciążonego będzie porównywalna dla wybranych wariantów profili powierzchni ślizgowych obu pierścieni uszczelniających. Nawet wartość minimalnej grubości filmu olejowego w newralgicznych punktach położenia tłoka, pomiędzy powierzchnią ślizgową górnego pierścienia uszczelniającego a gładzią cylindra w suwie rozprężania, biorąc pod uwagę którykolwiek $\mathrm{z}$ wariantów profili, nie zmienia się na tyle, aby zakłócić przebieg ciągłości filmu olejowego. Jest to spowodowane odciążającym działaniem ciśnień brzegowych w miejscu odwarstwienia i rozpoczęcia filmu olejowego.

Ważnym parametrem decydującym o wyborze optymalnego wariantu profilu powierzchni ślizgowej pierścieni uszczelniających jest jego wpływ na docisk górnego pierścienia uszczelniającego do gładzi cylindra siłami gazowymi, co w konsekwencji wpływa na objętość oleju wyciskanego w kierunku komory spalania $\mathrm{V}_{2} \mathrm{i}_{4}$ (tab. 3). Po przeliczeniu wartości tych objętości można ustalić wartość jednostkowego i godzinowego zużycia oleju. Na objętość zgarnianego oleju w suwie sprężania i wylotu wpływa głównie pokrycie powierzchni ślizgowej filmem olejowym. Na podstawie wyników symulacji można przyjąć, że pod wpływem zmiany w wariantach 1-5 profilu powierzchni ślizgowej pierścieni uszczelniających w stosunku do profilu referencyjnego pierścienia uszczelniającego, znacznie wzrasta zużycie oleju. To bardzo komplikuje zasadność stosowania powyższych wariantów profili powierzchni ślizgowej do zmniejszania strat tarcia pierścieni uszczelniających. Pomimo tych ograniczeń, można zauważyć, że warianty 1, 3 i 4 mają najlepsze właściwości w stosunku do pozostałych wariantów profili pierścieni uszczelniających. Spowodowane jest to korzystnym pokryciem profilu powierzchni ślizgowej filmem olejowym. Należy również zauważyć, że w warunkach rzeczywistych wprowadzenie rowków z wariantu 1, 3 i 4 będzie prowadzić do zwiększenia nacisków jednostkowych na gładź cylindra, a zatem będzie skutkować lepszym uszczelnieniem i zmniejszeniem zużycia oleju.

Jednostkowe i godzinowe zużycie oleju oraz objętości oleju wyciskanego w kierunku GMP dla różnych kątów po- 
onto the cylinder face, and consequently a better sealing and decrease in oil consumption.

The results of single and hourly consumption and the volume of oil squirted towards top dead centre for various position angles of the lateral piston area in relation to cylinder face marked with the letters M, L i R are presented in Table 3. Based on Fig. 1-6 and the data from Table 3 it can be claimed that the consumption of oil considerably depends on the pressure from the divergent slot occurring over the ring depending on the piston motion direction and the external pressure for the convergent side of lubricating slot between the ring and the cylinder face. Variants 1,3 and 4 ensure an acceptable distribution of oil film thickness for all the range of crankshaft rotation angle in all the engine strokes and guarantee partial covering of the profile of the sliding surface of the upper ring seal. According to preliminary findings even if the circumferential groove depth and its total axial height increase, variants 1, 3 and 4 provide acceptable conditions for creating an even oil film.

The most promising results are obtained for variant 3 of the profile of the sliding surface of ring seals - Fig. 5 . This is due to placing the circumferential groove on the sliding surface profile of the ring seal on the side of engine crankcase. Thanks to this the upper ring sliding surface is covered with a thinner layer of oil during the compression stroke. During this time the convergent slot becomes narrower and so the oil film volume is lower, which helps limit friction losses. When the piston changes its direction after passing the top dead centre at the backing stroke, where the pressure in oil film increases, conditions to create convergent slot are also favourable. Moreover, creating a buffer space under the upper seal ring can speed up the utilisation effects, which means better sealing of the cylinder by increased unit pressure, better lubrication conditions, lower friction losses and more effective driving heat energy from that ring. By resigning from the upper circumferential groove for the upper seal ring, as was the case in equally favourable variants 1 and 4 , the sedimentation of hydrocarbons produced during combustion is prevented. In this area of sliding surface introducing grooves with their small geometrical measurements can lead to their contamination with hydrocarbon particles and their final disappearance when the engine has been used for a long time. Such contamination of grooves with combustion products will certainly decrease the engine durability. The synthetic oils currently produced can effectively prevent this.

As the author found, in order to ensure fluid friction at all the crucial turning points of the piston from $5^{\circ}$ to $20^{\circ}$ after top dead centre at the backing stroke the convergent slot must be created on the axial height of the sliding surface of the ring on the side of the crankcase. Variant 3, in which the circumferential groove has been positioned on the side of the combustion chamber, assumes partial covering of the profile of the sliding surface of ring seals with oil film on the side of the crankcase soon after top dead centre at the backing stroke. Such a distribution of oil film on the sliding surface of the upper ring seal helps reduces friction losses and provides conditions to create fluid friction between the łożenia bocznej powierzchni tłoka względem gładzi cylindra, oznaczonego literami M, L i R, przedstawiono w tabeli 3. Na podstawie rysunków 1-6 oraz danych zamieszczonych w tabeli 3 można stwierdzić, że zużycie oleju w dużym stopniu zależy od wartości ciśnienia od strony szczeliny dywergentnej, występującej nad pierścieniem, w zależności od kierunku ruchu tłoka, oraz od wartości ciśnienia zewnętrznego dla strony konwergentnej szczeliny smarnej miedzy pierścieniem a gładzią. Warianty 1, 3 i 4 zapewniają akceptowalny rozkład grubości filmu olejowego dla całego zakresu kąta OWK we wszystkich suwach pracy silnika i gwarantują częściowe pokrycie profilu powierzchni ślizgowej górnego pierścienia uszczelniającego. Według wstępnych wyników, nawet przy wzroście głębokości i szerokości rowka obwodowego warianty 1, 3 i 4 dają akceptowalne warunki do powstania ciągłego filmu olejowego.

Najbardziej obiecujące wyniki badań symulacyjnych uzyskuje się dla wariantu 3. profilu powierzchni ślizgowej pierścieni uszczelniających - rysunek 5. Spowodowane jest to umieszczeniem rowka obwodowego na profilu powierzchni ślizgowej pierścienia uszczelniającego od strony skrzyni korbowej silnika. Dzięki temu uzyskuje się pokrycie mniejszą grubością filmu olejowego profilu powierzchni ślizgowej górnego pierścienia podczas suwu sprężania. W tym czasie szczelina konwergentna charakteryzuje się mniejszą szerokością, a zatem występuje tam mniejsza objętość filmu olejowego, co sprzyja zmniejszeniu strat tarcia. W momencie zmiany kierunku tłoka po przejściu przez punkt GMP w suwie rozprężania, gdzie występuje znaczy przyrost ciśnienia w filmie olejowym, warunki do tworzenia szczeliny konwergentnej są również korzystne. Ponadto stworzenie przestrzeni buforowej pod górnym pierścieniem uszczelniającym może przyspieszyć efekty utylitarne, polegające na polepszeniu uszczelnienia cylindra przez wzrost nacisków jednostkowych, stworzeniu lepszych warunków smarowania, zmniejszeniu strat tarcia i efektywniejszym odprowadzeniu energii cieplnej z tego pierścienia. Przez rezygnację z wprowadzenia górnego rowka obwodowego dla górnego pierścienia uszczelniającego, jak to jest w równie korzystnych wariantach 1 i 4, dodatkowo przeciwdziała się osadzaniu węglowodorów w tych rowkach podczas zachodzących w silniku procesów spalania. W tym obszarze powierzchni ślizgowej pierścienia wprowadzenia rowków obwodowych przy nieznacznych ich wymiarach geometrycznych może spowodować ich zanieczyszczenie osadzającymi się cząstkami węglowodorów, aż do całkowitego ich zaniknięcia w dłuższym okresie eksploatacji silnika. Takie zanieczyszczenie rowków obwodowych produktami spalania z pewnością wpłynie na zmniejszenie trwałości silnika. Obecnie produkowane oleje syntetyczne mogą skutecznie temu przeciwdziałać.

$\mathrm{Na}$ podstawie autorskich ustaleń, dla zapewnia tarcia płynnego w najbardziej newralgicznych zwrotnych punktach tłoka od $5^{\circ}$ do $20^{\circ}$ po GMP w suwie rozprężania, szczelina konwergentna musi tworzyć się na osiowej wysokości powierzchni ślizgowej pierścienia po stronie skrzyni korbowej silnika. Wariant 3, w którym wprowadzono rowek obwodo- 
Table 3. Oil consumption for selected variants of profiles of sliding surfaces of ring seals

Tabela 3. Wyniki zużycia oleju dla wybranych wariantów profili powierzchni ślizgowej pierśsieni uszczelniających

\begin{tabular}{|c|c|c|c|c|c|c|c|}
\hline $\begin{array}{l}\text { Variant of the } \\
\text { profile of ring } \\
\text { sliding surface/ } \\
\text { wariant profilu } \\
\text { powierzchni } \\
\text { ślizgowej } \\
\text { pierścienia }\end{array}$ & $\begin{array}{l}\text { Piston position } \\
\text { in relation to } \\
\text { cylinder face/ } \\
\text { polożenie ttoka } \\
\text { względem gładzi } \\
\text { cylindra }\end{array}$ & $\begin{array}{c}\text { Unit oil } \\
\text { consumption/ } \\
\text { jednostkowe } \\
\text { zużycie oleju } \\
\mathrm{g}_{0}[\mathrm{~g} / \mathrm{kWh}]\end{array}$ & $\begin{array}{c}\text { Hourly oil } \\
\text { consumption/ } \\
\text { godzinowe } \\
\text { zużycie oleju } \\
\mathrm{G}_{\mathrm{h}}[\mathrm{g} / \mathrm{h}]\end{array}$ & $\begin{array}{c}\text { Volume of oil } \\
\text { scraped to the com- } \\
\text { bustion chamber in } \\
\text { inlet stroke/objętość } \\
\text { oleju zgarnianego } \\
\text { do komory spalania } \\
\text { w suwie dolotu } \mathrm{V}_{1} \\
{\left[\mathrm{~mm}^{3}\right]} \\
\end{array}$ & $\begin{array}{l}\text { Volume of oil scraped } \\
\text { to the combustion } \\
\text { chamber in backing } \\
\text { stroke/objętość } \\
\text { oleju zgarnianego do } \\
\text { komory spalania w } \\
\text { suwie sprężania } \mathrm{V}_{2} \\
{\left[\mathrm{~mm}^{3}\right]} \\
\end{array}$ & $\begin{array}{l}\text { Volume of oil } \\
\text { scraped to the com- } \\
\text { bustion chamber } \\
\text { in working stroke/ } \\
\text { objętość oleju zgar- } \\
\text { nianego do komory } \\
\text { spalania w suwie } \\
\text { pracy } \mathrm{V}_{3}\left[\mathrm{~mm}^{3}\right]\end{array}$ & $\begin{array}{l}\text { Volume of oil scraped } \\
\text { to combustion cham- } \\
\text { ber in the outflow } \\
\text { stroke/objętość oleju } \\
\text { zgarnianego do kon- } \\
\text { mory spalania w suwie } \\
\text { wylotu } \mathrm{V}_{4}\left[\mathrm{~mm}^{3}\right]\end{array}$ \\
\hline \multirow[t]{3}{*}{1} & M & 39.97 & 4.0 & 0.026 & 0.105 & 0.086 & 0.043 \\
\hline & L & 8.79 & 0.9 & 0.002 & 0.021 & 0.026 & 0.012 \\
\hline & $\mathrm{R}$ & 50.07 & 5.0 & 0.061 & 0.130 & 0.551 & 0.055 \\
\hline \multirow[t]{3}{*}{2} & M & 17.03 & 1.7 & 0.001 & 0.052 & 0.116 & 0.011 \\
\hline & L & 718.00 & 71.7 & 0.001 & 2.501 & 0.623 & 0.155 \\
\hline & $\mathrm{R}$ & 101.00 & 10.1 & 0.018 & 0.308 & 0.164 & 0.067 \\
\hline \multirow[t]{3}{*}{3} & M & 49.07 & 4.9 & 0.018 & 0.139 & 0.075 & 0.042 \\
\hline & $\mathrm{L}$ & 3.64 & 2.9 & 0.035 & 0.013 & 0.057 & 0.000 \\
\hline & $\mathrm{R}$ & 58.53 & 5.8 & 0.035 & 0.158 & 0.409 & 0.058 \\
\hline \multirow[t]{3}{*}{4} & $\mathrm{M}$ & 38.92 & 3.9 & 0.026 & 0.101 & 0.120 & 0.043 \\
\hline & $\mathrm{L}$ & 13.58 & 1.4 & 0.004 & 0.025 & 0.003 & 0.025 \\
\hline & $\mathrm{R}$ & 42.88 & 4.3 & 0.114 & 0.104 & 0.811 & 0.055 \\
\hline \multirow[t]{3}{*}{5} & M & 4.53 & 0.5 & 11.267 & 0.015 & 11.282 & 0.001 \\
\hline & $\mathrm{L}$ & 16166.00 & 1613.0 & 34.261 & 21.899 & 43.236 & 37.873 \\
\hline & $\mathrm{R}$ & 110.00 & 11.0 & 0.014 & 0.292 & 0.158 & 0.117 \\
\hline \multirow{3}{*}{$\begin{array}{l}\text { Reference/refer- } \\
\quad \text { encyjny }\end{array}$} & M & 11.92 & 1.2 & 0.008 & 0.027 & 0.060 & 0.017 \\
\hline & $\mathrm{L}$ & 486.00 & 48.5 & 2.088 & 1.543 & 2.811 & 0.253 \\
\hline & $\mathrm{R}$ & 26.01 & 2.6 & 0.026 & 0.048 & 0.079 & 0.048 \\
\hline
\end{tabular}

mating surfaces. Reducing friction power results mainly from limiting the volume of oil which occurs in the convergence slot regardless of piston motion direction, and at a crucial turning point of the piston an acceptable thickness of oil film between cylinder face and the sliding surface of the upper ring seal is ensured.

The oil volume scraped to the combustion chamber by the sliding surface of the upper ring seal variant 3 is also lower or comparable with the oil amount for the other profile variants of the sliding surfaces of ring seals. This is due to gathering a lower volume of oil in the angle crankshaft rotation angle from $180^{\circ}$ to $360^{\circ}$, where pressure values in the oil film are much lower than after piston turning point top dead centre at backing stroke. Moreover, theoretical volume of oil scraped to the combustion chamber during compression and outflow is lower than in real-life conditions of piston combustion engine operating.

The initially assumed low depth of circumferential grooves mean that their influence on the oil flow around the piston grooves is minimal. The influence can be significant for more effective cooling of the ring, particularly the seal ring. To define that variant 3 of the sliding surface must be thoroughly examined with a larger depth exceeding the threshold of piston groove. The examination should also include the calculation of influence of the volume of oil gathered in the buffer area on the volume of heat taken from the upper seal ring. The friction loss can be more significantly reduced with a ring seal of lower axial height than by modifying the shape of the sliding surface of the rings. However, this will very negatively influence oil wy od strony skrzyni korbowej zakłada częściowe pokrycie profilu powierzchni ślizgowej pierścieni uszczelniających filmem olejowym po stronie skrzyni korbowej tuż po GMP w suwie rozprężania. Takie rozłożenie filmu olejowego na powierzchni ślizgowej górnego pierścienia uszczelniającego sprzyja redukcji strat tarcia i zapewnia korzystne warunki do zainicjowania tarcia płynnego. Zmniejszenie mocy tarcia wynika przede wszystkim ze zmniejszenia objętości oleju występującego w szczelinie konwergentnej, niezależnie od kierunku ruchu tłoka, a w krytycznym punkcie zwrotnym tłoka zapewnia dopuszczalną grubość filmu olejowego między gładzią cylindra a powierzchnią ślizgową górnego pierścienia uszczelniającego.

Zgarniana ilość oleju smarującego do komory spalania przez powierzchnię ślizgową górnego pierścienia uszczelniającego z wariantu 3. jest nieznaczna lub porównywalna z ilością oleju pozostałych wariantów profili powierzchni ślizgowych pierścieni uszczelniających. Jest to spowodowane zabieraniem mniejszej objętości oleju w zakresie kąta OWK od $180^{\circ}$ do $360^{\circ}$, gdzie wartość ciśnień w filmie olejowym jest dużo mniejsza niż po punkcie zwrotnym tłoka tuż po GMP w suwie rozprężania. Należy nadmienić, że teoretyczna objętość oleju zgarnianego do komory spalania w suwie sprężania i wylotu jest mniejsza niż w rzeczywistych warunkach eksploatacji tłokowego silnika spalinowego.

Z wstępnie przyjętych nieznacznych wartości głębokości rowków obwodowych wynika, że w minimalnym stopniu wpływają one na zmianę przepływu oleju wokół rowków pierścieniowych tłoka. Wpływ ten może być znaczący 
film parameters. So it can be claimed that the application of circumferential grooves is more advantageous in reducing friction losses. Moreover, the application of a piston ring of standard axial height, but limiting only the direct mating surfaces does not significantly influence its durability and the increased risk of breaking the ring in the piston groove which works under a large load.

\section{Conclusion}

Meeting the conditions which favour fluid friction in all the range of crankshaft rotation angle, regardless of engine load and its operation conditions is the main condition to justify the method of shaping the geometry of a profile of a sliding surface of the lower and upper ring seal while limiting friction losses in the piston-cylinder assembly.

Based on the simulation conducted the following conclusions can be drawn:

- Implementing circumferential grooves on the profile of the sliding surface of ring seals helps to reduce friction losses by reducing the areas which directly mate with the piston, and does not change the axial height of the piston rings.

- Unchanged axial height of the ring helps to maintain its particular durability and own resilience force after changing the geometry of the reference ring sliding surface.

- Reducing the area directly mating with the cylinder face with unchanged axial height of the ring leads to increased unit pressure of the ring onto the cylinder face and improves the tightness of the kinematic set.

- Application of centrally placed circumferential rings on the profile of the sliding surface of seal rings is ineffective, as it reduces friction losses insignificantly and leads to unfavourable covering of the ring sliding surface with oil and increased oil consumption.

- Implementing circumferential grooves on the external part of the sliding surface of the seal ring leads to reduction in friction losses while maintaining favourable parameters of oil film, the durability of the kinematic set and increased oil consumption. The latter can be prevented by changing the distances between the rings in the set.

- Application of a circumferential groove on the side of the crankcase on the ring sliding surface, provided the depth and width are properly selected, can create a buffer space for oil, which will help to draw the heat from ring surface and provide better conditions for kinematic set lubrication.

The concept of shaping the convergent slot and its pressures for the most advantageous variant of a profile of the sliding surface of seal rings with circumferential groove placed on the side of the crankcase for various ranges of crankshaft rotation angle in terms of optimising oil film parameters and possibilities to reduce the power absorbed by ring seals in order to overcome internal friction in oil film requires further theoretical research and experiments. The authors' further theoretical and experimental studies will concern the influence of changes of depth and width of circumferential grooves of a particular profile variant of ring sliding surfaces on the friction losses, oil film parameters and oil consumption. Also it will be necessary to study the influence of a change in oil volume gathered in the buffer dla efektywniejszego chłodzenia pierścienia, zwłaszcza uszczelniającego. W tym celu należy szczegółowo przebadać wariant 3 profilu powierzchni ślizgowej pierścienia uszczelniającego przy zwiększonej głębokości przekraczającej próg rowka pierścieniowego tłoka. Badanie powinno także obejmować obliczenie wpływu objętości zgromadzonego oleju w przestrzeni buforowej na ilość odprowadzanego ciepła z górnego pierścienia uszczelniającego. Większą redukcję strat tarcia można uzyskać, stosując pierścień uszczelniający o mniejszej wysokości osiowej, niż modyfikując kształt powierzchni ślizgowej pierścieni uszczelniających. Takie działanie jednak wpływa bardzo niekorzystnie na parametry filmu olejowego. Zatem można stwierdzić, że stosowanie rowków obwodowych kształtujących geometrię pierścienia jest bardziej korzystne w zmniejszaniu strat tarcia. Ponadto, stosując pierścienień tłokowy o standardowej wysokości osiowej, ale ograniczając wyłącznie powierzchnie bezpośredniego kontaktu z gładzią nie wpływa się znacznie na jego wytrzymałość i zwiększenie ryzyka pęknięcia pierścienia w rowku tłoka pracującego pod dużym obciążeniem.

\section{Podsumowanie}

Spełnienie wymogów sprzyjających powstaniu tarcia płynnego w całym zakresie kąta OWK, niezależnie od obciążenia silnika i warunków jego eksploatacji, stanowi o zasadności stosowania metody kształtowania geometrii profilu powierzchni ślizgowej dolnego i górnego pierścienia uszczelniającego podczas zmniejszania strat tarcia w grupie tłokowo-cylindrowej.

Na podstawie danych z przeprowadzanych badań symulacyjnych można przedstawić następujące wnioski:

- Wprowadzenie rowków obwodowych na profilu powierzchni ślizgowej pierścieni uszczelniających prowadzi do zmniejszenia strat tarcia przez redukcję powierzchni bezpośrednio współpracującej z gładzią cylindra, a nie zmienia osiowej wysokości pierścieni tłokowych.

- Niezmienna osiowa wysokość pierścienia uszczelniającego przyczynia się do zachowania przez niego określonej wytrzymałości i siły sprężystości własnej po zmianie geometrii powierzchni ślizgowej pierścienia referencyjnego.

- Zmniejszenie powierzchni bezpośrednio współpracującej z gładzią cylindra przy niezmiennej osiowej wysokości pierścienia prowadzi do wzrostu nacisków jednostkowych pierścienia na gładź cylindra i poprawy uszczelnienia złożenia kinematycznego.

- Zastosowanie centralnie rozmieszczonych rowków obwodowych na profilu powierzchni ślizgowej pierścieni uszczelniających jest nieefektywne, bowiem daje nieznaczną redukcję strat tarcia przy niekorzystnym pokryciu profilu powierzchni ślizgowej pierścienia olejem oraz wzroście zużycia oleju.

- Wprowadzenie po zewnętrznej części profilu powierzchni ślizgowej pierścienia uszczelniającego rowków obwodowych skutkuje zmniejszeniem strat tarcia, przy zachowaniu korzystnych parametrów filmu olejowego, zachowaniu trwałości złożenia kinematycznego oraz wzroście zużycia oleju, któremu można skutecznie przeciwdziałać przez zmianę wzajemnej odległości pierścieni w pakiecie. 
space of the circumferential groove on the efficiency of drawing the heat from the upper seal ring. Simulations will be conducted concerning the changes in oil flow resulting from creating the buffer space on the ring sliding surface, on the area of cylinder face and the piston groove mating with the working areas of seal rings. Also tribological studies of sliding surfaces of seal rings after a modification of profile shape with cylinder face must be conducted. These studies will help to evaluate the point in introducing the grooves as creating the buffer space for oil, reducing friction losses, improving lubrication parameters for the mating pair and increasing durability of piston rings.

\section{Bibliography}

[1] Derndinger, H. Konstruktive Mittel zur Leistungssteigerung von Fahrzeugmotoren. ATZ, 1967, nr 3.

[2] Groth, K. Neuere Methodezur Untersuchung von Reibverlusten in Motorentriebwerken. Schiff und Hafen/Kommandobrucke, 1977, nr 10.

[3] Iskra, A., Wiśniewski T. Wpływ kształtu powierzchni ślizgowej pierścienia tłokowego na zużycie zespołu pierścień- tuleja i oleju smarującego, Silniki Spalinowe, 1981/1.

[4] Iskra, A., Wiśniewski T. Wpływ ruchów poprzecznych tłoka na zużycie rowków pierścieniowych i pierścieni, Kones'87, Lublin - Kazimierz Dolny 25-27.11.1987.

[5] Iskra, A. Modele matematyczne warunków tworzenia filmu olejowego na gładzi cylindrowej. Problemy rozwojowe silników spalinowych, Szczecin 1984.

[6] Iskra, A. Rozkład filmu olejowego na gładzi cylindrowej silnika tłokowego. Rozprawy nr 181. Wydawnictwo Politechniki Poznańskiej, Poznań 1987.

[7] Iskra, A. Studium konstrukcji i funkcjonalności pierścieni w grupie tłokowo-cylindrowej. Wydawnictwo PP, Poznań 1996.

[8] Niewczas, A., Koszałka, G., Guzik, M. Modeling of collaboration between the piston ring and the piston groove shelf in an internal combustion engine. Eksploatacja i Niezawodność 4, 2006.

[9] Serdecki, W. Analysis of ring pressure distribution on a deformed cylinder face. Journal of POLISH CIMAC. Energetic aspects, Vol. 7, No.1, Gdańsk 2012.

[10] Serdecki, W. Znaczenie poprawności opisu profilu pierścienia tłokowego w procesie modelowania jego współpracy z gładzią cylindra. Journal of Kones - Internal Combustion Engines. Warsaw 1999.

[11] Tian, T., Noordzij, L.B., Wong, V.W., Heywood, J.B. Modeling piston-ring dynamics, blowby, and ring-twist effects. Journal of Engineering for Gas Turbines and Power, 120 (4), 1998.

[12] Tian, T. Dynamic Behaviors of Piston Rings and Their Practical Impact - Part II: Oil Transport, Friction, and Wear of Ring/ Liner Interface and the Effects of Piston and Ring Dynamics, Proc. Inst. Mech. Eng., Part J: Journal of Engineering Tribology, 216, 2002.

Piotr Wróblewski, MEng. - doctoral student in the Faculty of Machines and Transport at Poznan University of Technology.

Mgrinż. Piotr Wróblewski - doktorant na Wydziale Maszyn Roboczych i Transportu Politechniki Poznánskiej.

e-mail: piotrje.wroblewski@doctorate.put.poznan.pl

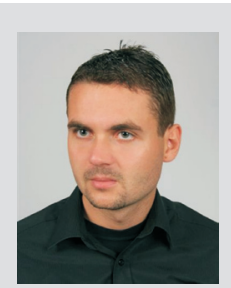

- Zastosowanie rowka obwodowego po stronie skrzyni korbowej na powierzchni ślizgowej pierścienia uszczelniającego o odpowiednio dobranej głębokości i szerokości może utworzyć przestrzeń buforową dla oleju, co będzie sprzyjać odprowadzaniu ciepła z powierzchni pierścienia i zapewni lepsze warunki smarowania złożenia kinematycznego.

Dokładna weryfikacja koncepcji kształtowania szczeliny konwergentnej i przebiegających w niej ciśnień dla najbardziej korzystnego wariantu profilu powierzchni ślizgowej pierścieni uszczelniających $\mathrm{z}$ rowkiem obwodowym umieszczonym od strony skrzyni korbowej dla różnych przedziałów kąta OWK, w aspekcie optymalizacji parametrów filmu olejowego i możliwości ograniczania mocy pochłanianej przez pierścienie uszczelniające na pokonanie tarcia wewnętrznego w filmie olejowym, wymaga dalszych badań teoretycznych i doświadczalnych. Autorskie badania teoretyczne i eksperymentalne będą w następnych etapach obejmować analizę wpływu zmiany głębokości i szerokości rowków obwodowych zastosowanych w wybranym wariancie profilu powierzchni ślizgowej pierścieni na straty tarcia, parametry filmu olejowego oraz zużycie oleju. Niezbędne są również badania wpływu zmiany objętości oleju zgromadzonego w utworzonej przestrzeni buforowej rowka obwodowego na skuteczność odprowadzania ciepła z górnego pierścienia uszczelniającego. Wykonane będą badania symulacyjne zmian przepływu oleju wskutek utworzenia przestrzeni buforowej na powierzchni ślizgowej pierścienia, na obszarze kontaktu gładzi cylindra i rowka tłoka z powierzchnią roboczą pierścieni uszczelniających. Istnieje również konieczność przeprowadzenia badań tribologicznych ślizgowych płaszczyzn powierzchni pierścieni uszczelniających po modyfikacji kształtu profilu z gładzią cylindra. Badania takie będą miały na celu ocenę słuszności wprowadzania rowków obwodowych jako tworzących przestrzeń buforową dla oleju, zmniejszającą straty tarcia, polepszającą parametry smarowania pary współpracującej i zwiększającą odporność na zużycie pierścieni tłokowych.

[13] Wolff, A., Piechna, J. Numerical simulation of piston ring pack operation. The Archive of Mechanical Engineering, Vol. L, 3, 2003.

[14] Wolff, A., Piechna, J. Numerical simulation of piston ring pack operation in the case of mixed lubrication, The Archive of Mech. Engineering, Vol. LII, No. 3, 2005.

[15] Wolff, A. Numerical analysis of piston ring pack operation of a marine two-stroke engine, Combustion Engines, 3, 2011.

Prof. Antoni Iskra, DSc., DEng. - Professor in the Faculty of Machines and Transport at Poznan University of Technology.

Prof. dr hab. inż. Antoni Iskra - profesor na Wydziale Maszyn Roboczych i Transportu Politechniki Poznańskiej.

e-mail: antoni.iskra@put.poznan.pl

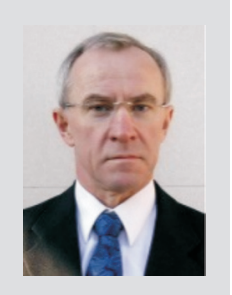

